
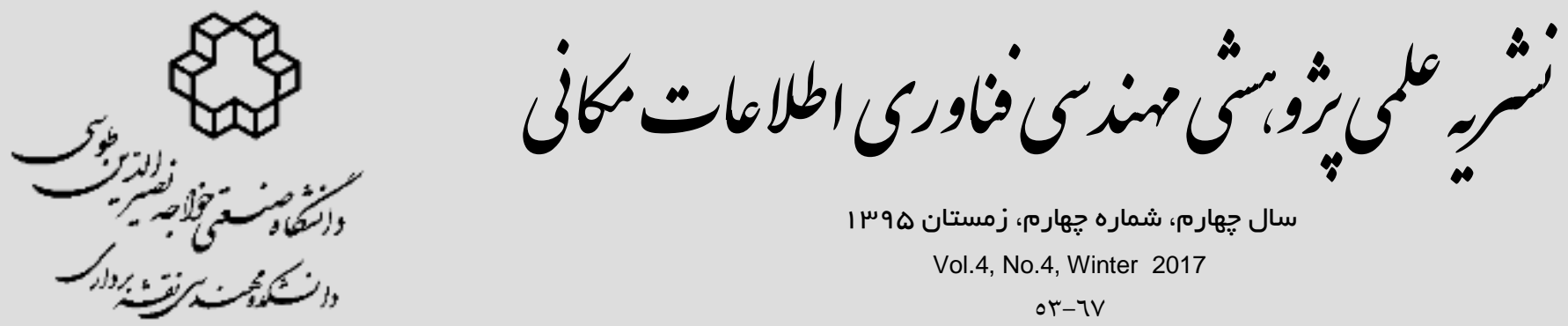

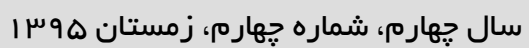

Vol.4, No.4, Winter 2017

or-TV

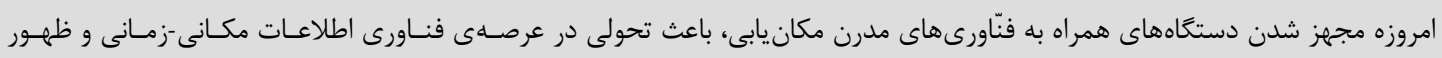

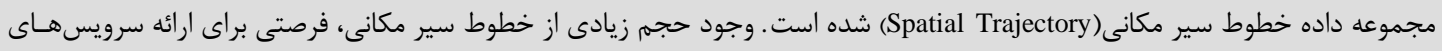

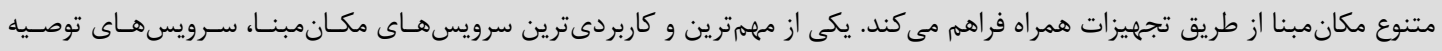

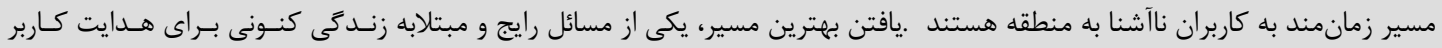

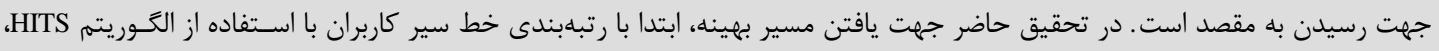

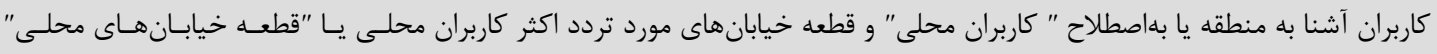

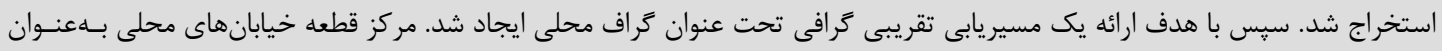

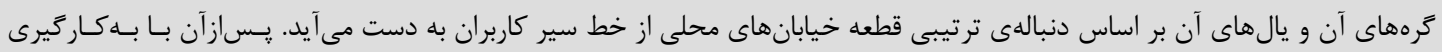

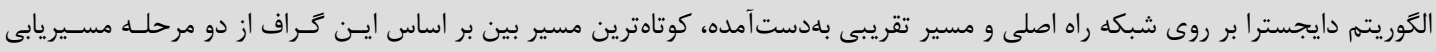

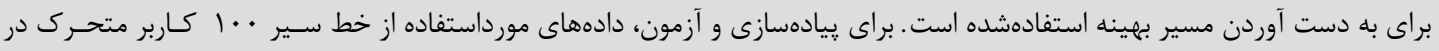

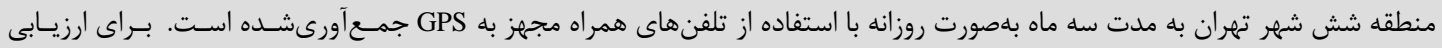

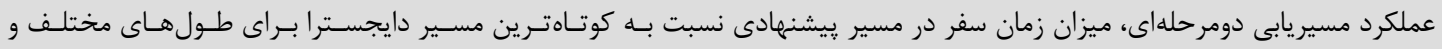

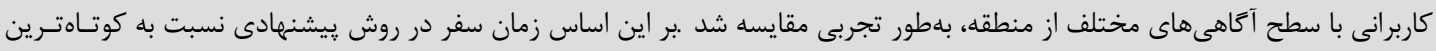
مسير حدود ب و درصد كاهش يافت.

$$
\text { كليدوازهها: توصيه مسير، خط سير، الكوريته رتبهبندى، كاربران و قطعه خيابانهاى محلى. }
$$

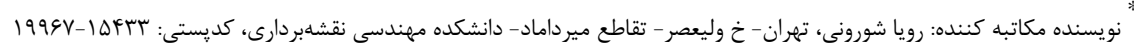


متوالى كه داراى مؤلفـهـ هـاى مكـانى زمــانى هســتند،

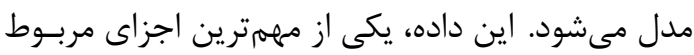

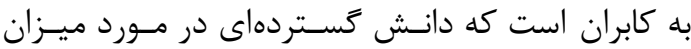

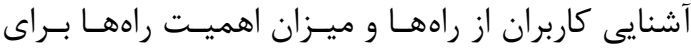

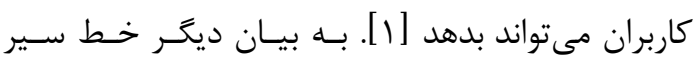

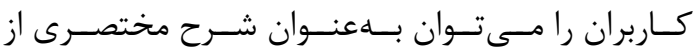
رفتارهاى مكـرر كـاربر، در دو بعـد مكـان (مكـانهـاى

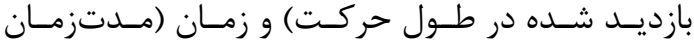
حركت) تعريف كرد. اخيرا سرويسهـاى توصسيه مسـير

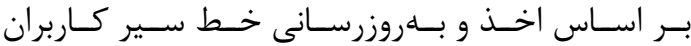

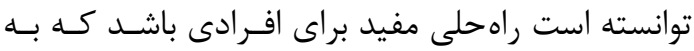
دنبال سفر به منطقهاى هستند كه با آن آشنايى ندارند. در اينجا سامانهاى ارائهشـده كـهـ در آن رانــدكانى كـهـ

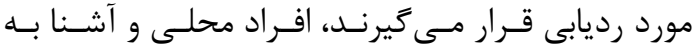

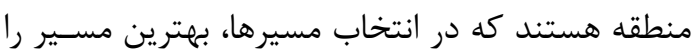

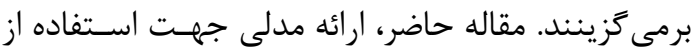
دادههـاى خـط سـير ثبـت شــده توسـط غنى نمودن دادهاى معابر براى مسير يـابى در منـاطق

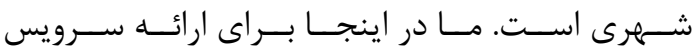
توصيه مسير بر اساس رفتار حركتى افراد محلـى، خـط إنط سير تعدادى از كاربران مجهز به وسيله نقليه شخصى راسئ بررسى و مدلسازى مى كنيه. در ادامه، فصل دو بيشينه

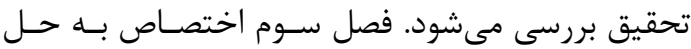

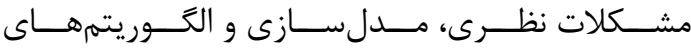
توسعه دادهشده دارد. يِيادهازى و ارزيابى سـرويس در در

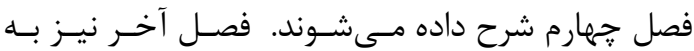
نتيجه كيرى و جمعبندى اختصاصيافته است.

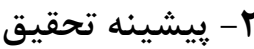

داده هــاى GPS بـــراى اتصـال موقعيـت جغرافيـايى و

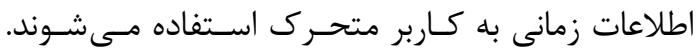

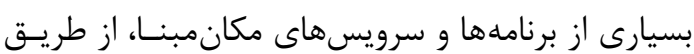

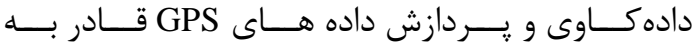
اسـتخر اج اطلاعـات معنسى دار در كاربردهــاى مختلـف

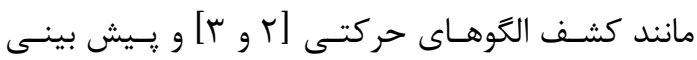

- 1- - 1قدمه

با توجه به افزايش ترافيـك و بـهـ دنبـال آن زيـادشـدن زمان سفر در شهرهاى بزرى مانند تهران، ارائه راهحلى

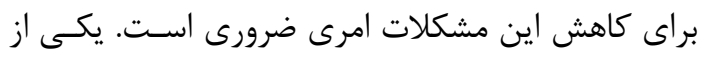

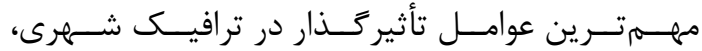
يافتن مسير بهينه براى رسيدن به مقصد اسـت. يـافتن مسير بهينه يكى از اصلىترين فعاليـتهـيـي اسـت كـهـ

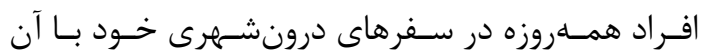
مواجه مىشوند. در واقع مسيريابى به يك فعاليت روزانه

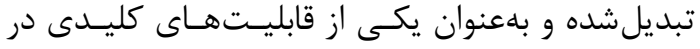
سرويسهايى جون Google Maps در دسـترس عمـوم قراركرفته است. اما متأسفانه در حسال حاضـر در تهـــان هيج كونه سامانه مديريت ناوكانى بـراى كـاربران سـواره

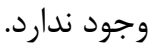
اصولاً مردم براى انتخاب يك مسير يا عدم انتخـاب آن

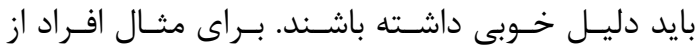

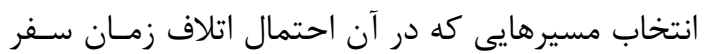

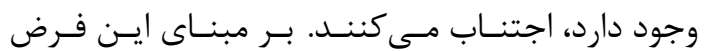
مى توان مسئله را اين گُونه تعريف كرد كه مسـيرهايى را

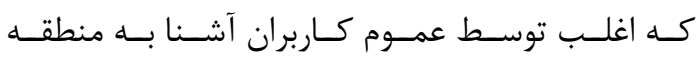
مورداستفاده قرار مى گيرند، با هدف كشف واقعيتهـاى تاري ينهان از طريق داده كاوى بهدسـت بيـاوريم. زيــرا افـراد

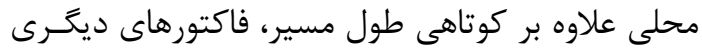

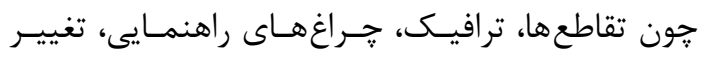

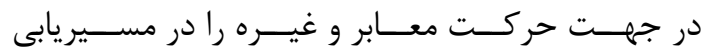
لحاظ مى كنند. اما شناخت كـاربران محلى و و آشــنا بـهـ منطقه مسئلهاى است كه جز تحليل رفتار حركتى آنها

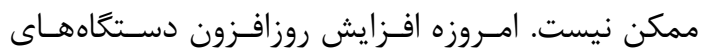
متحرى و فنّاورىهاى موقعيتيابى، منجر به حجم انبوه

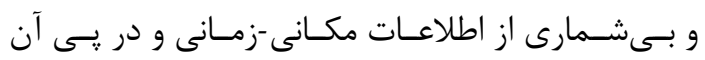

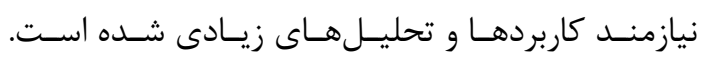

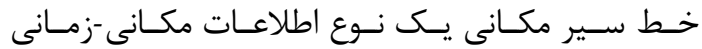

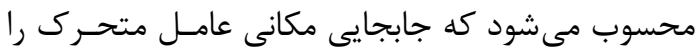

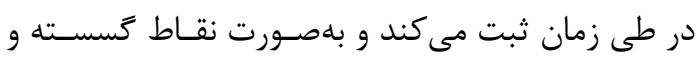


معين، مشابه است و بـراى كـاربران حـق انتخــاب بــين

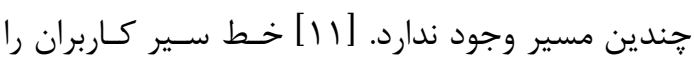

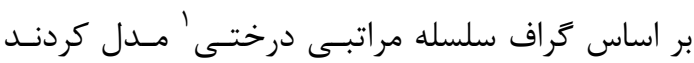

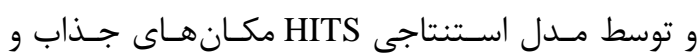

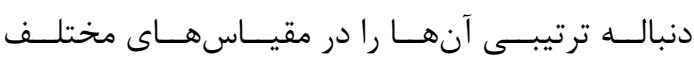

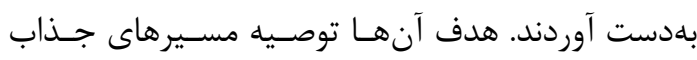

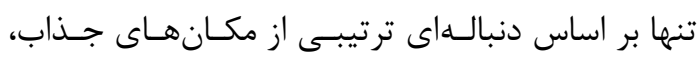

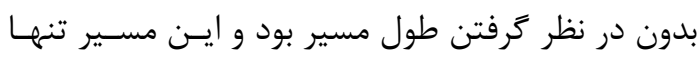
براى توصيه به كردشكران مناسب است.

سيسـتههــاى توصـيه مسـير بـهـطـور كلـى دو دسـته

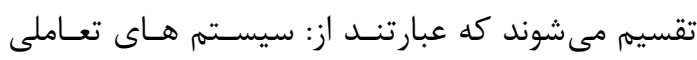

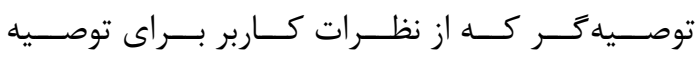

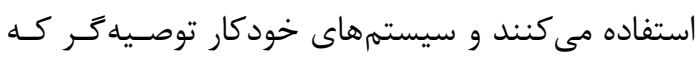

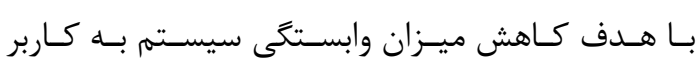

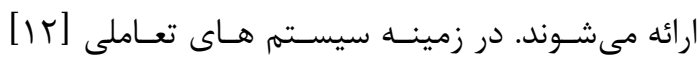

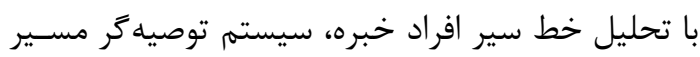

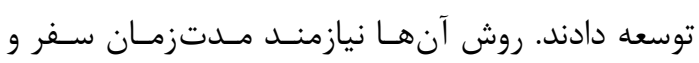

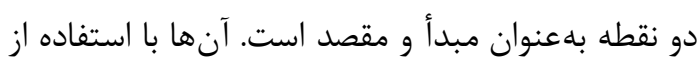

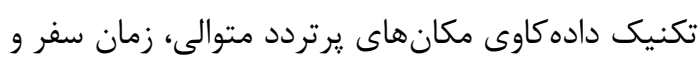

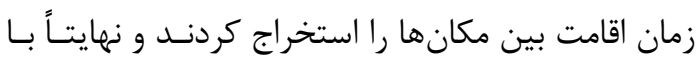
اطلاعات بهدستآمده براى مكانها و ارتباط بـ بـين آنهـا

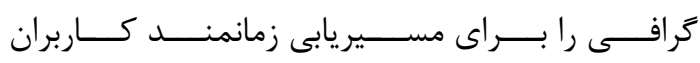
توسعه مى دهند. [بآ] يكى سيستم تعاملى توصيه مسير

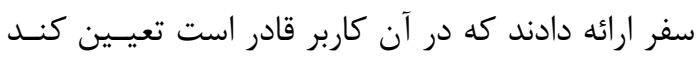

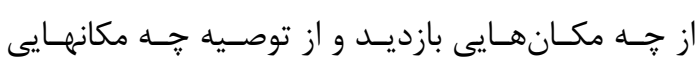

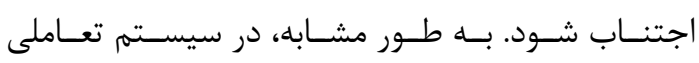

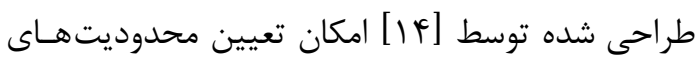

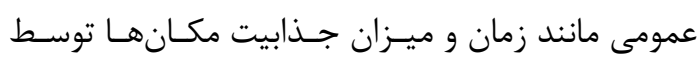

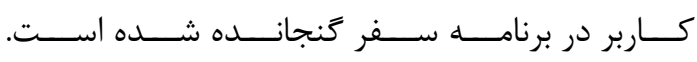
جنين سيستمهاى تعاملى بيشتر براى كاربران آشنا بـهـ

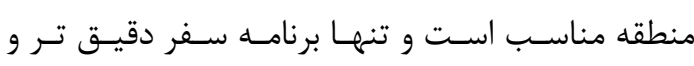
جزئى ترى به كاربر ارائه مى شود و براى كاربران نا آشــنا

\footnotetext{
${ }^{1}$ tree-based hierarchical graph
}

الكوى تكرارى [ץ] هستند. يردازش دادههاى خام GPS

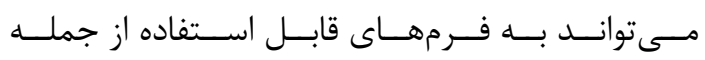

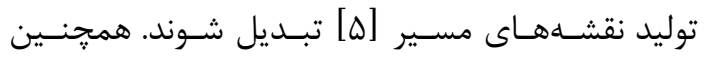

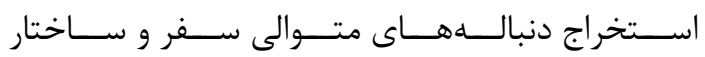

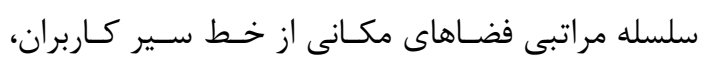

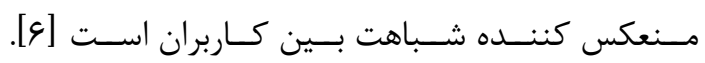

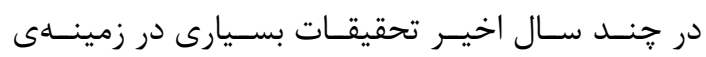

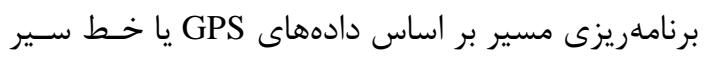

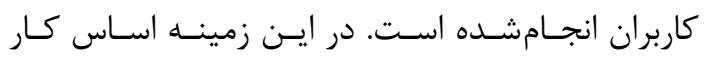

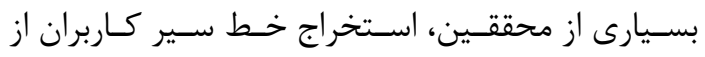
دادههاى GPS ثبتشده توسط آنها و استفاده از آنهـا

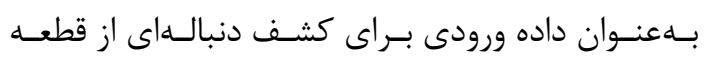

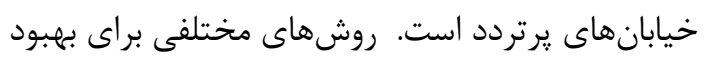

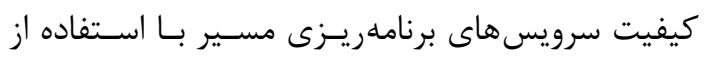
خط سير كاربران معرفىشدهاند و ايده اصلى آنها آنها ايجاد

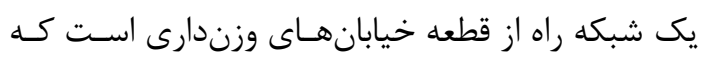

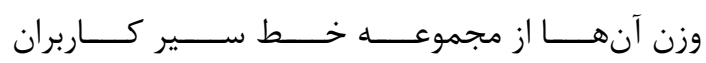

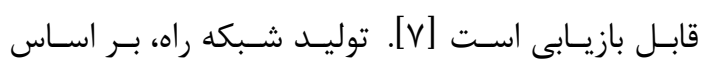

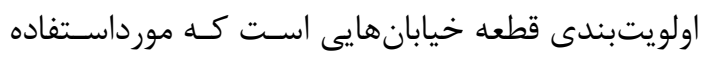

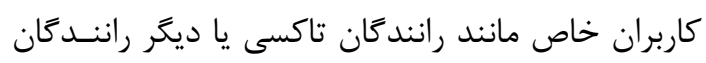

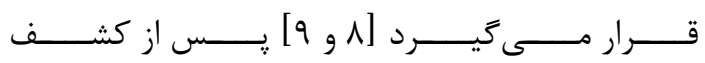

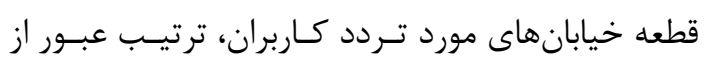

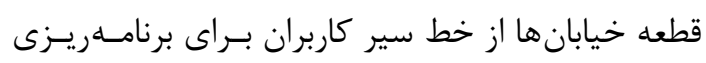

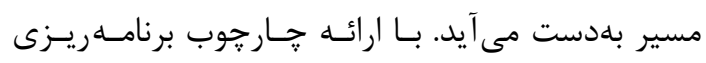

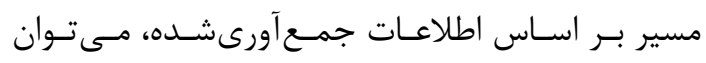

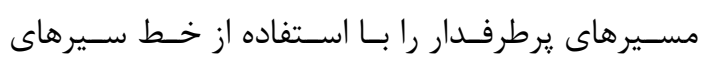

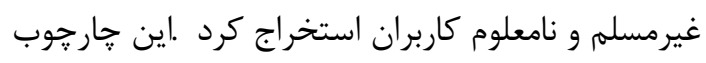

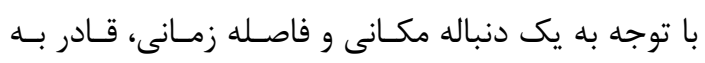

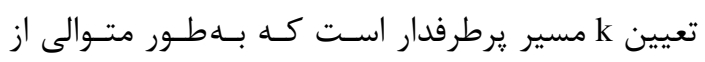

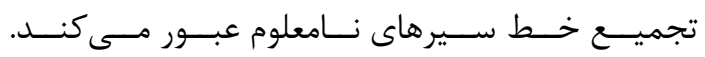

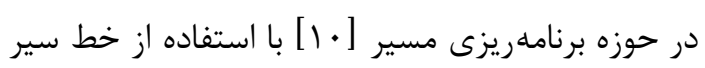

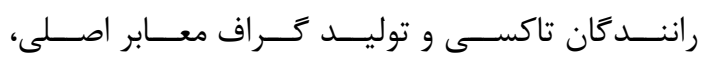

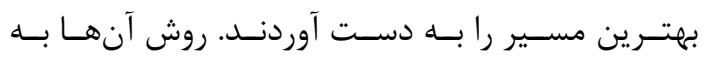

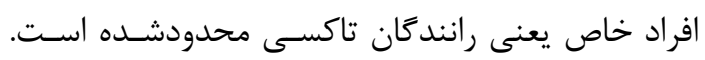

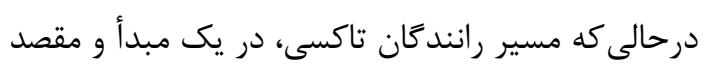




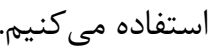

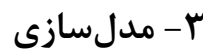

در سيستمهاى توصيه مسير با توجه به شرايط ترافيكى

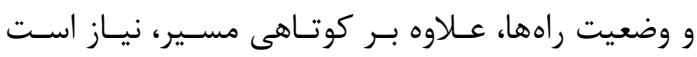

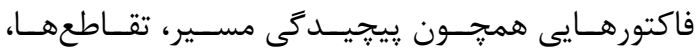

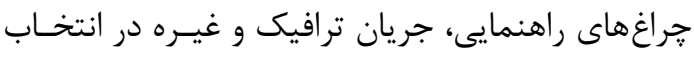

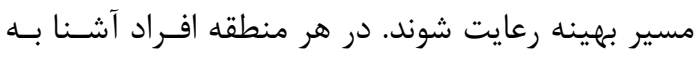

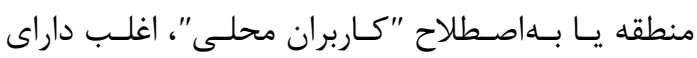

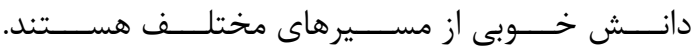

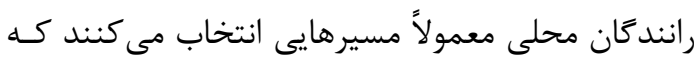

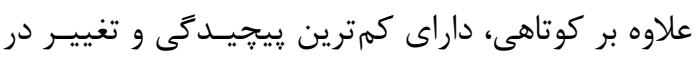

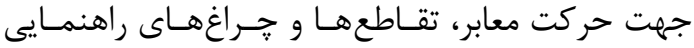
باشد. در هر منطقه سرويسهاى توصيه مسير مى توانند

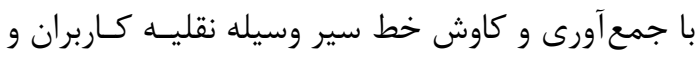

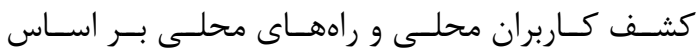

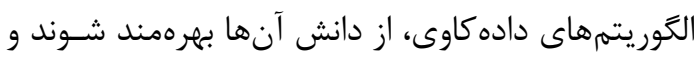

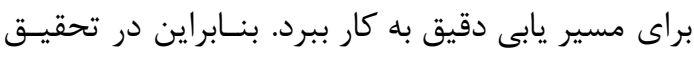

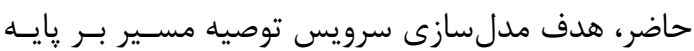

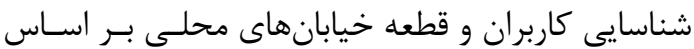

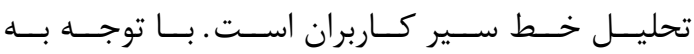
اهداف ذكر شده شكل (1)، مراحل شكل خيـرى اجـزاى مورد استفاده مدل را نشان مى دهد.
به منطقه، عملى و قابل استفاده نمىباشد. در حوز0ى سيستم هـاى خودكـار، [ه 1] يـك سيسـتم

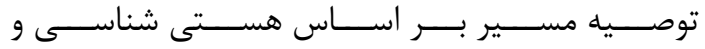
برآورد ترجيحات كابران با استفاده از اطلاعات نـاهمكن هئن

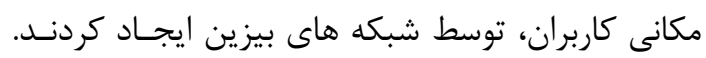

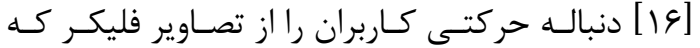

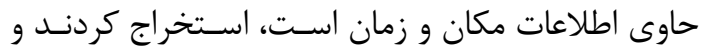

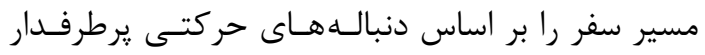

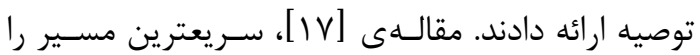

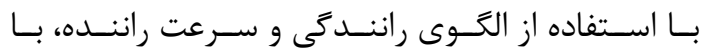

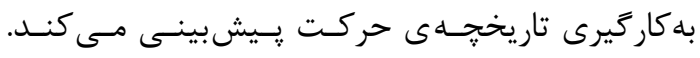

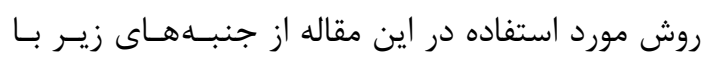

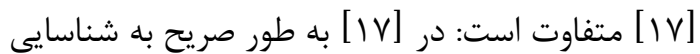
الكوى رانندگى و سرعت وسايل نقليـه يرداختـهـ اسـت،

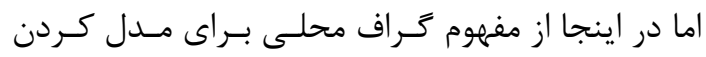
هوش رانندكان محلى استفاده شده است. كراف محلى آلى آلى

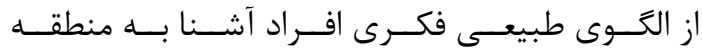
پيروى مى كند و بهينه تـرين مسـير را ارائسه مسى كنـد. هدف اين مقاله، توصيه خودكار مسير بر اساس يردازئن خط سير كـاربران محلـى اسـت. ورودى سيسـتم تنهـا

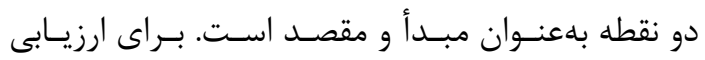

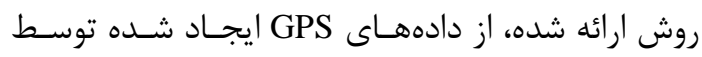
كاربران واقعى بـهمنظـور بهـرهورى خروجـى الخــوريته

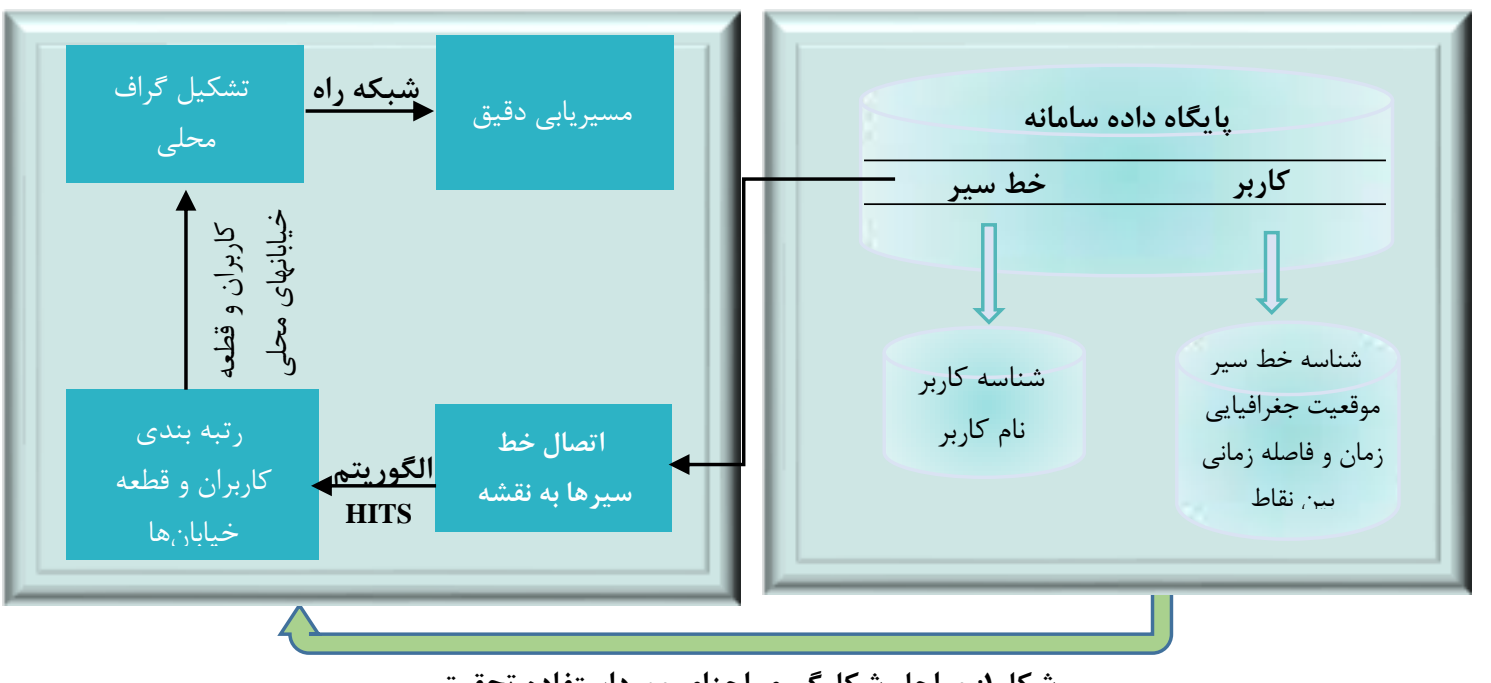

شكل ا: مراحل شكل كيرى اجزاى مورداستفاده تحقيق 
مسير تقريبى بهدستآمده از مرحله قبل بهصورت آنى محا محاسبه مىشود. خروجى اين دو مرحله، يكى مســير بـر

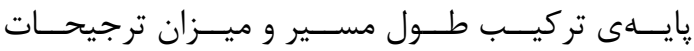
كاربران محلى است. هركاه خط سير افـراد بـروز شـود،

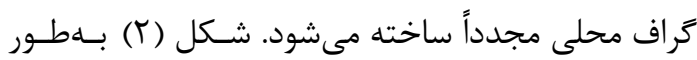
خلاصه مراحل مسيريابى دومرحلهاى را نشان مىدهدئ

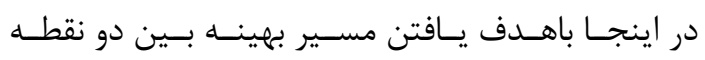

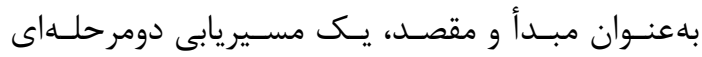

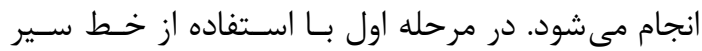

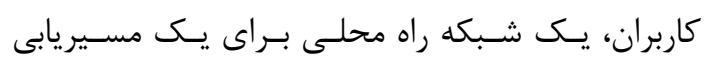

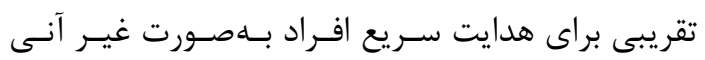

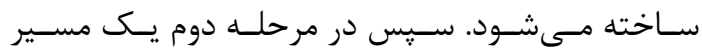

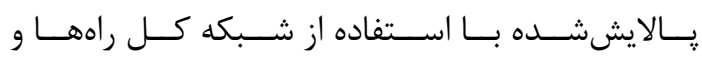

كراف محلى براساس يالهاى محلى و ارتباط بين يالها

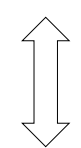

اتصال خط سير كاربران محلى بر شبكه راه

$+$

شبكه راه
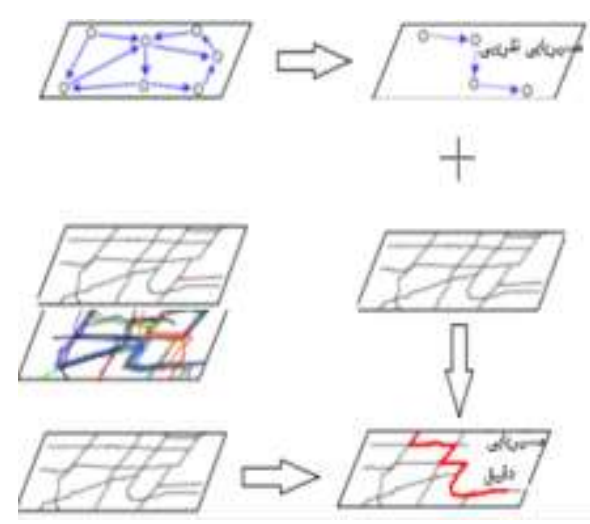

ش'لل ז: مراحل روش پييشنهادى مسيريابى دومرحلداى

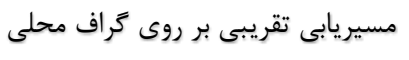
(از يك يال محلى به يال محلى ديكر)

نَاشت نقاط پيموده شده بر روى شبكه راه $+$ مسير دقيق r.e وr. r. r.e; r.s, r.e E به ترتيب نقاط ابتدايى و انتهايى قطعه خيابان هستند. خط سير، دنبالهى ترتيبى از نقاط GPS است كه به فرم

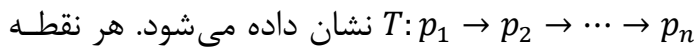

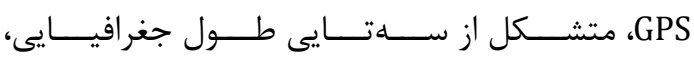
عرض جغرافيايى و زمان است. براى استفاده از خط سير كـاربران درروش يِيشـنهادى،

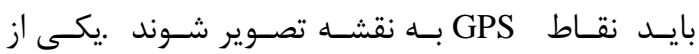

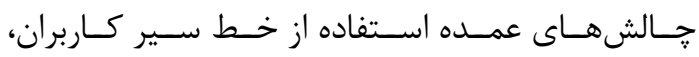

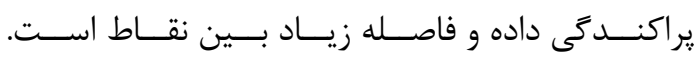
زيرا كاربران به علت عدم دسترسى بله اينترنت فاصن در تمـام

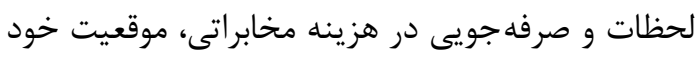

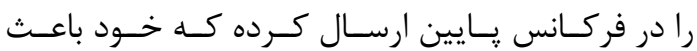

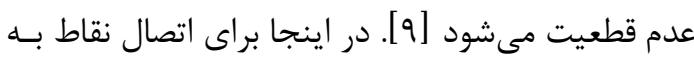
نقشه از روش 'IVMM كه يكى از مناسبترين روشهاي اتصال نقاط بـا

\footnotetext{
${ }^{1}$ Interactive-voting based map matching
}

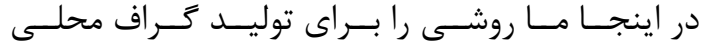

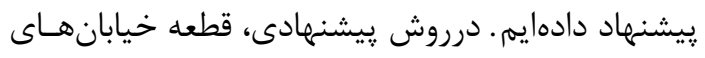
شبكهى راه، بر اساس خـط سـيرهاى عبـورى كـاربران بر اساس يك الكَوريته رتبهبندى، رتبهدهـى مسى شـوند.

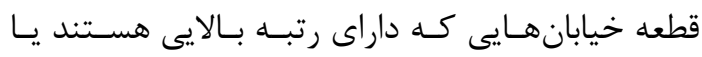

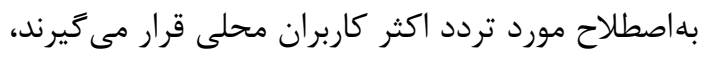

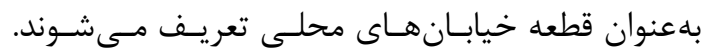

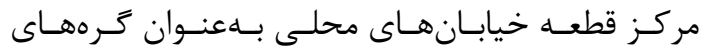

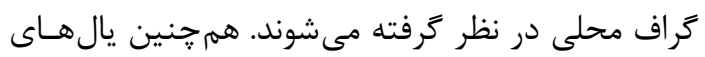

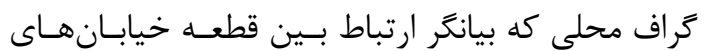

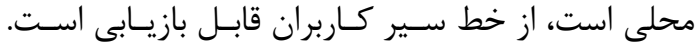

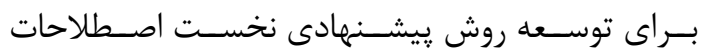

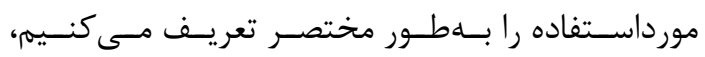
سيس به حل مسئله مى يردازيم.

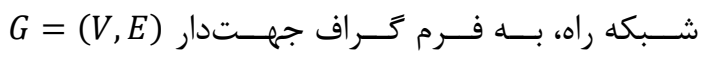

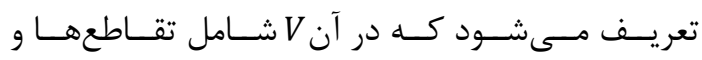
نقاط يايانى راهها و E مجموعهى قطعه خيابانها اسـت.

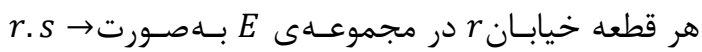




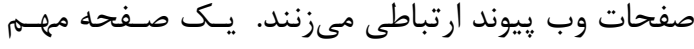
مى تواند صفحات معتبرى را در مورد يك موضوع خاص رئن ييشنهاد دهد، و يك صـفحه معتبـر توسـط بسـيارى از از صفحات مهم ارجاع داده شود. اين رابطه مدور منجر بـهـ تعريف الكوريتم تكرارى HITS مىشود.

در خايخاه داده خط سير كاربران، دو نوع مورد اطلاعـاتى

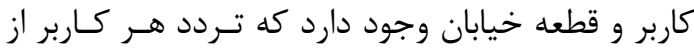

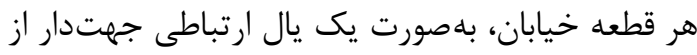

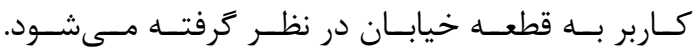
بر يايه مدل HITS هر كاربر بهعنوان يك مرجع Hub و

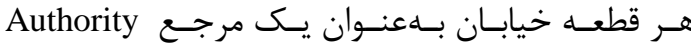

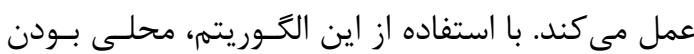
قطعه خيابانها و كاربران به ترتيب بـا محاسـبه ميـزان

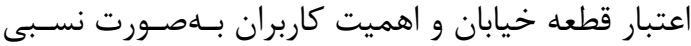

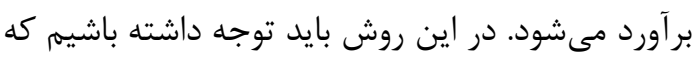

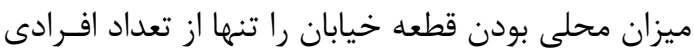

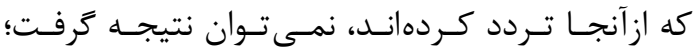

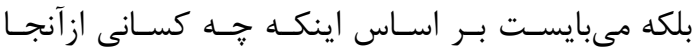

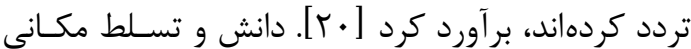

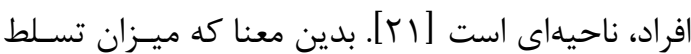

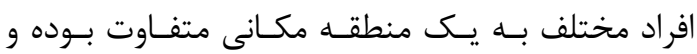

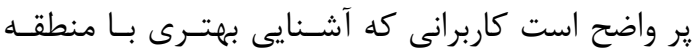

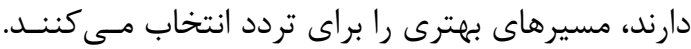
اخر سطح آشنايى كاربران با منطقه در نظر ترفته نشود، نتيجه رتبهبندى، قطعه خيابانهاى يرتردد و يرترافيـك

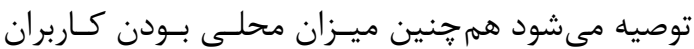

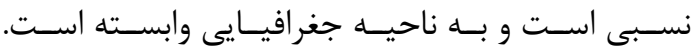
در واقع ممكن است كاربرى كه در يك منطقه دانش و و

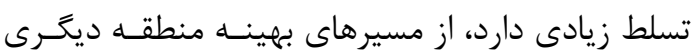
هيج اطلاعاتى نداشته باشد. بر اين رِايـه، ميـزان اعتبـار

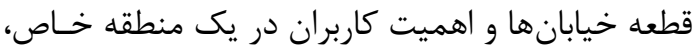
با در نظر كرفتن وابستخى اين دو مقـدار بـه يكـديكر و و

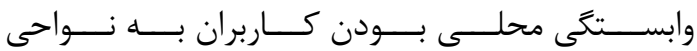

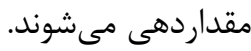

براى غلبه بر خطاهاى GPS اسـت، اسـتفاده مسىشـود

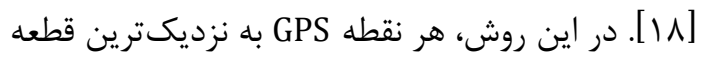
خيابان در شبكه راهها تصـوير مسىشـود و خـط سـيرها

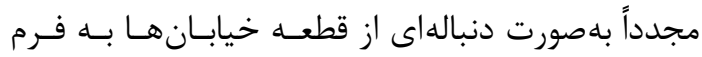
T: $r_{1} \rightarrow r_{2} \rightarrow \cdots \rightarrow r_{n}$ اولين قدم براى مدل سازى ترجيحات كاربران محلسى در

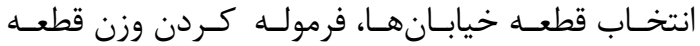

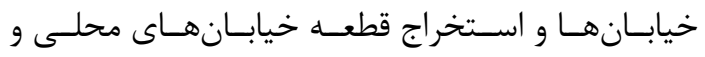
انتخاب مراكز آنها بهعنوان كرههاى كراف است.

r-1- كشف كاربران و قطعه خيابان هـاى محلـى توسط الكوريته HITS

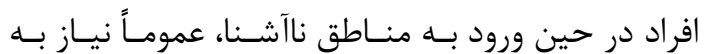
انتخاب مسيرهايى دارند كه آنها را در يافتن سـريعتر

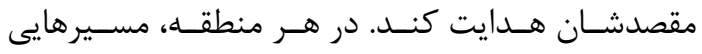

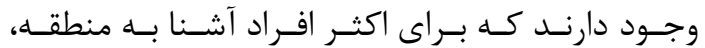
شناختهشده و بهينه است. براى كشف اين مسيرها كـهـ

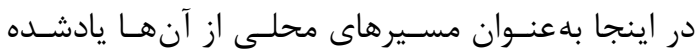

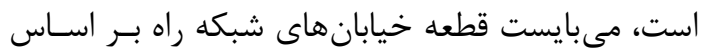

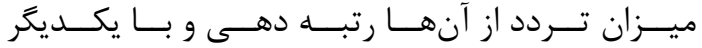

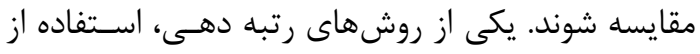

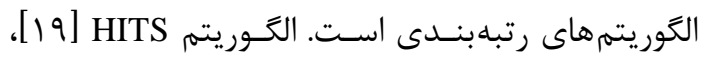

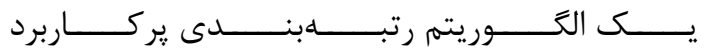

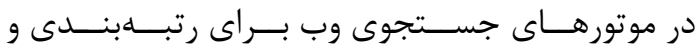

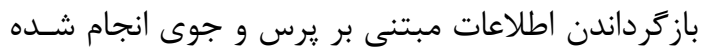

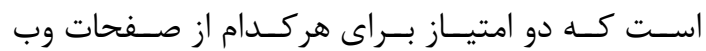

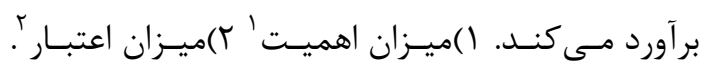

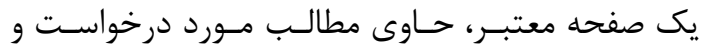

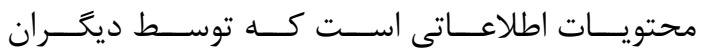

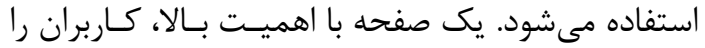
به جسـتوجـوى صـفحات معتبـر هـدايت مسى كننــد و

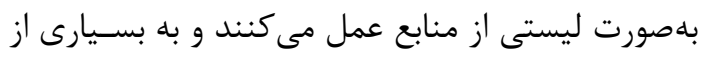

\footnotetext{
${ }^{1}$ Hub score

${ }^{2}$ Authority score
} 


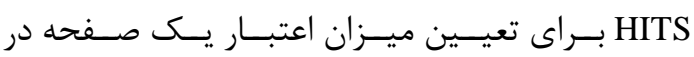

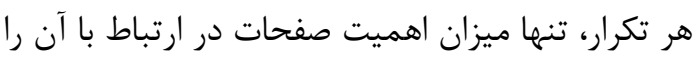

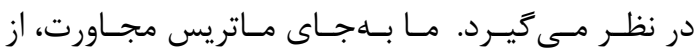

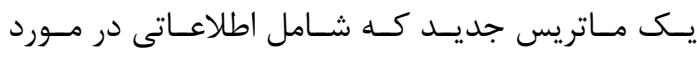

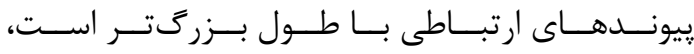

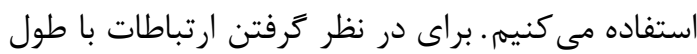

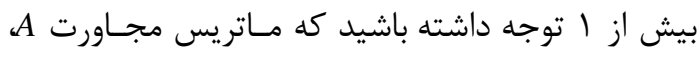

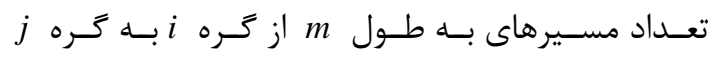

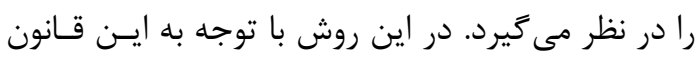

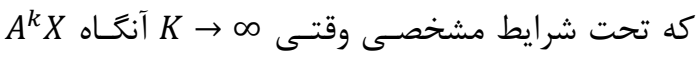

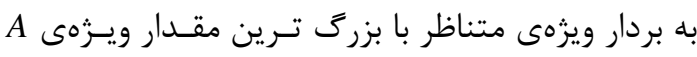

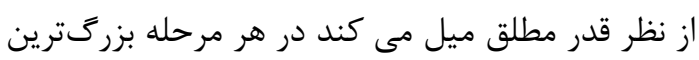

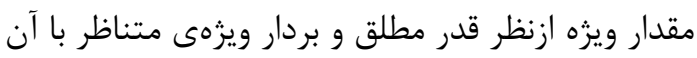

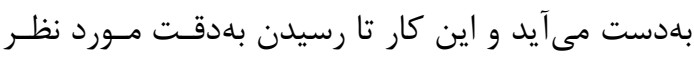

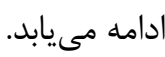

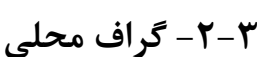

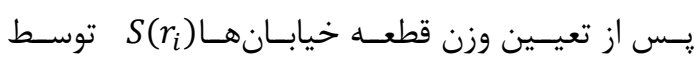
الكَوريتم HITS بر اساس ميزان تردد كـاربران محلـى و تشـكيل مجموعـــى

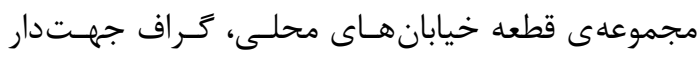

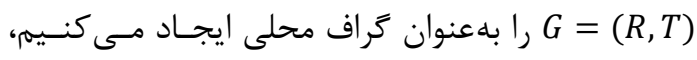

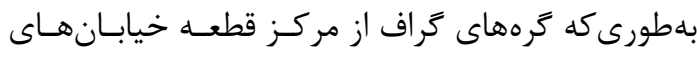

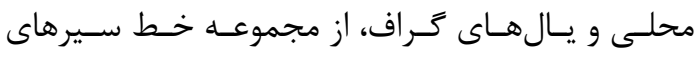

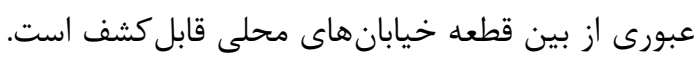

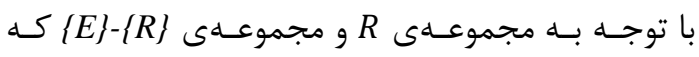
بيانكر مجموعهى قطعه خيابان هاى موجود در شبكه راه رجاه

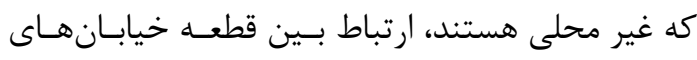

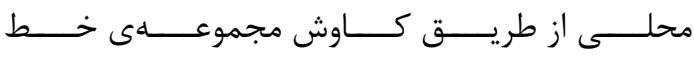

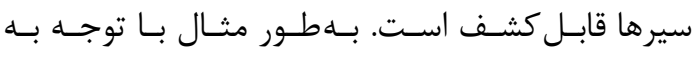
جدول (1)، قطعه خيابانهـاى محلى بـ

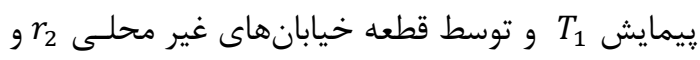

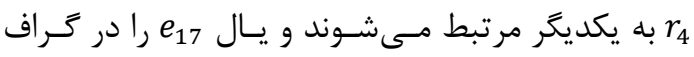

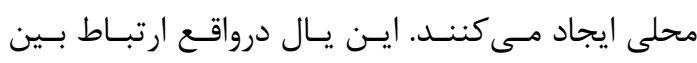
كرههاى

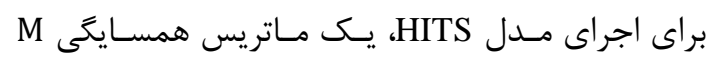

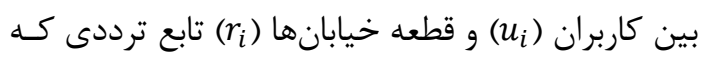

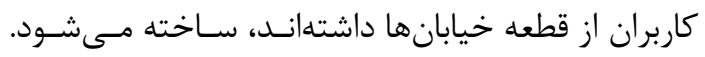
در اين ماتريس مقدار

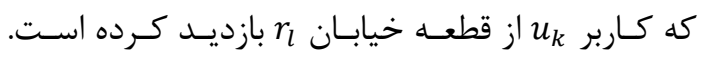

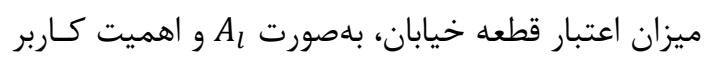
u بهورت

$$
M=\begin{array}{ccc}
r_{1} & \cdots & r_{n} \\
u_{1}\left[\begin{array}{ccc}
V_{1}^{1} & \cdots & V_{n}^{1} \\
\vdots & \ddots & \vdots \\
V_{1}^{n} & \cdots & V_{n}^{n}
\end{array}\right]
\end{array}
$$

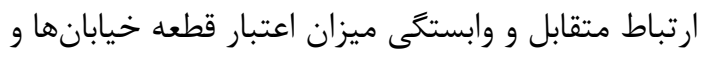
ميزان اهميت كاربران با روابط زير بيان مىشود: $A_{l}=\sum_{u_{k} \epsilon U} H_{k} \times V_{l}^{k}$ رابطه (1) $H_{k}=\sum_{u_{k} \epsilon U} A_{l} \times V_{l}^{k}$ (T) (T)

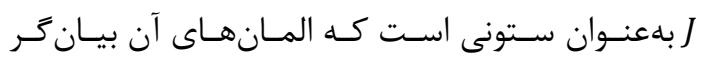

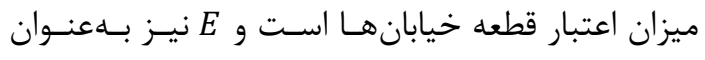

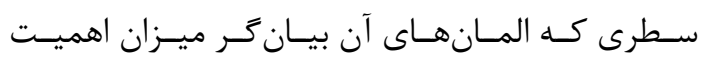

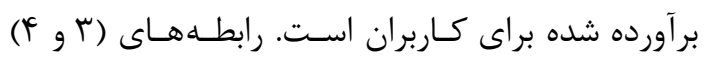
مى تواند بهصورت زير بازنويسى شود [1 [1 ]ـ:

$$
\begin{aligned}
& J=M^{T} . E \\
& \text { رابطه (r) } \\
& J=E^{T} . M \\
& \text { رابطه (f) }
\end{aligned}
$$

فرايند تكرارى محاسبه اهميـت افـراد و اعتبـار قطعـهـ خيابانها به فرم زير است [19] رابطه (ه) $J_{n}=M^{T} \cdot M \cdot J_{n-1}=\left(M^{T} \cdot M\right)^{n} \cdot J_{0} \quad$ (\&)

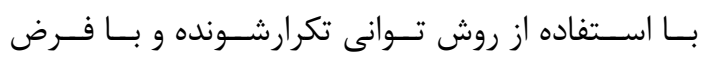
اعتبـار

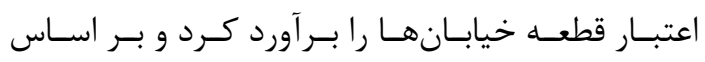

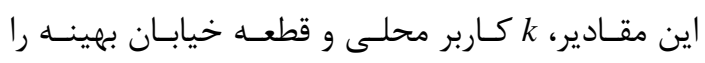
در ناحيه جستوجوى استخر اج كرد. 
آنها بهعنوان خره كر الف محلى در نظر ترفتـه مسىشـود.

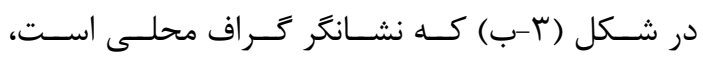

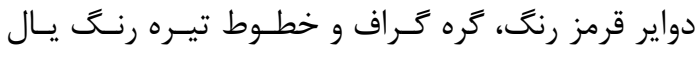

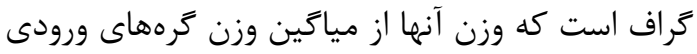
و خروجى و فاصله بين كرهها بهدست مى آيد.
همانطور كه در شكل(بَ-الف) مشاهده مىشود، خطـوط

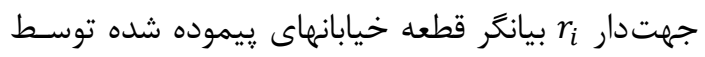

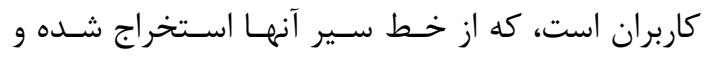

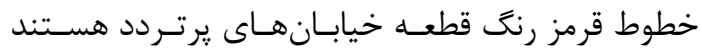

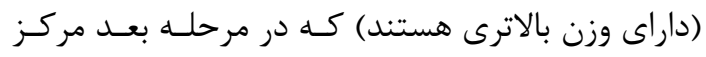
جدول ا: خط سيرها بهعنوان دنبالهاى از قطعه خيابانهاى محلى

\begin{tabular}{|c|c|c|}
\hline يال كراف & خيابان هاى مجله از قطعه & شناسه خط \\
\hline$e_{8-6}$ & $r_{8} \rightarrow r_{7} \rightarrow r_{6}$ & $T_{1}$ \\
\hline$e_{3-11}$ & $r_{3} \rightarrow r_{3} \rightarrow r_{1} \rightarrow r_{11}$ & $T_{2}$ \\
\hline$e_{3-8}$ & $r_{3} \rightarrow r_{2} \rightarrow r_{9} \rightarrow r_{8}$ & $T_{3}$ \\
\hline$e_{11-8}$ & $r_{1} \rightarrow r_{11} \rightarrow r_{10} \rightarrow r_{8}$ & $T_{4}$ \\
\hline
\end{tabular}

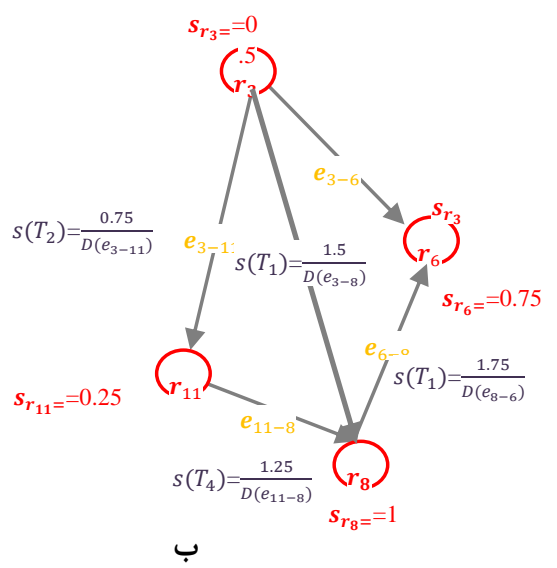

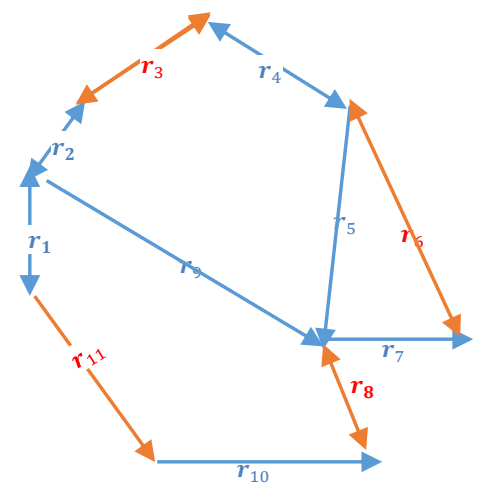

الف - 20 - 2

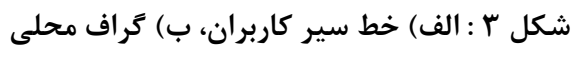

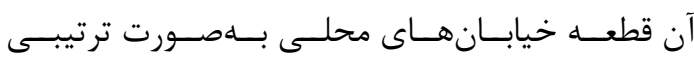

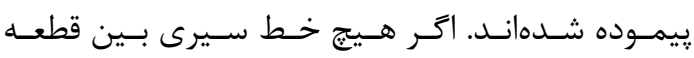

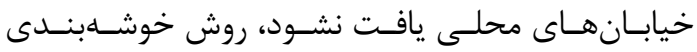

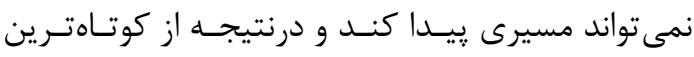
مسير مستقيم بين ميان مبدأ و مقصد، استفاده مى كند.

\section{ץ}

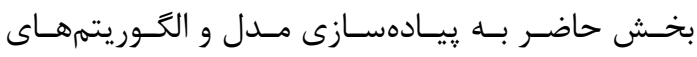

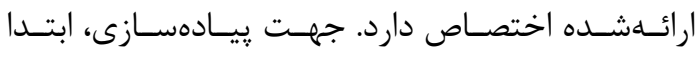

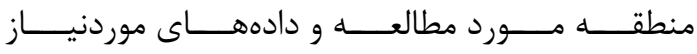

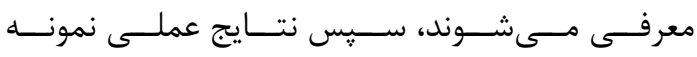

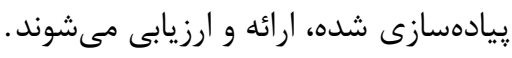

به بيان ديكر وزن يالهاى محلى، بلهـورت تركيبـى از

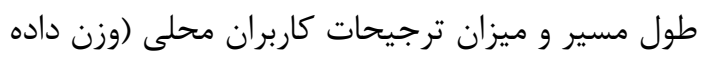

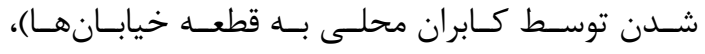
با توجه به معادله(V) قابلمحاسبه است [YT] توسل. $S(T)=\frac{\left(S\left(r_{s}\right)+S\left(r_{e}\right)\right) / 2}{\operatorname{distance}\left(r_{s}, r_{e}\right)} \quad$ (V) خ

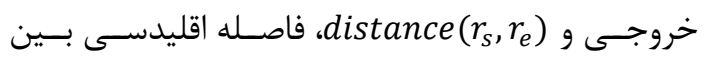
كرهها به واحد كيلومتر است. با تعيـين مبــأ و مقصــد،

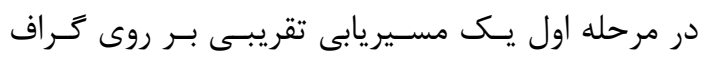

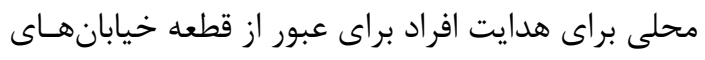
محلى، انجام مى شود. سيس توسط الكوريتم دايجسـترا

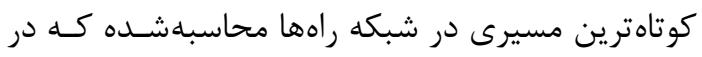




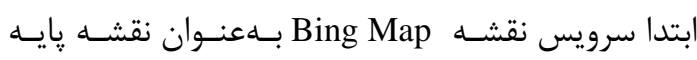

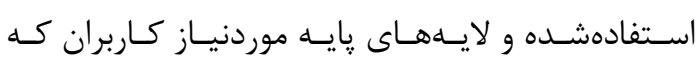
شامل شبكه راهها و نقشهى بلوك هاى ساختمانى اسـت

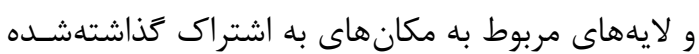

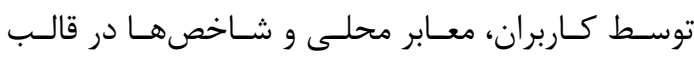

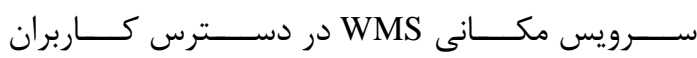

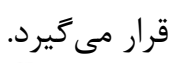

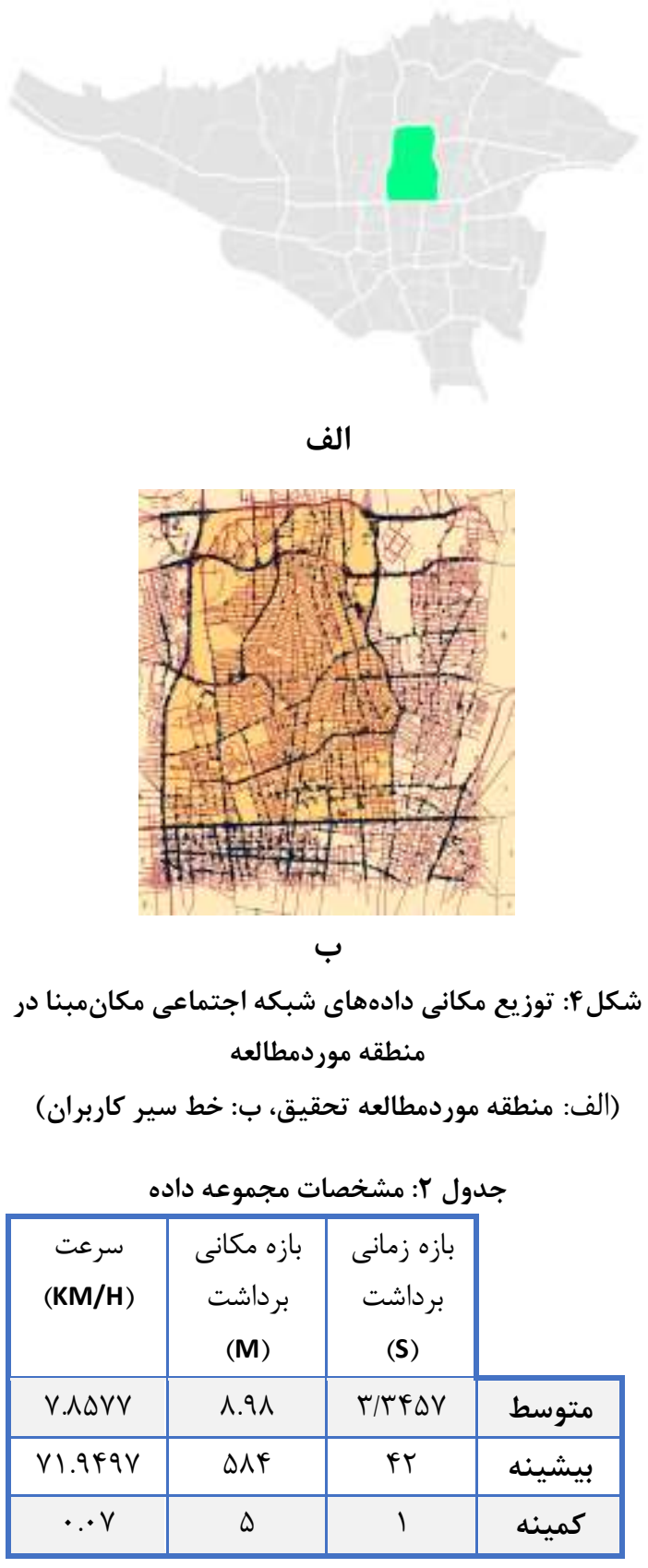

F - - F - منطقه موردمطالعه و دادههاى مورداستفاده

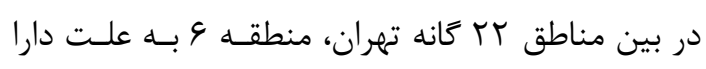

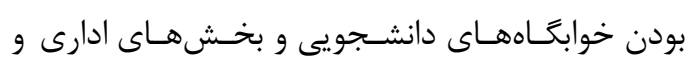

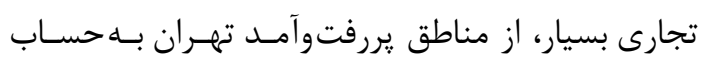

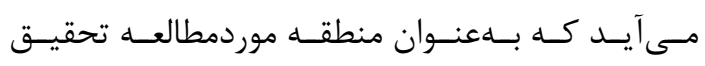

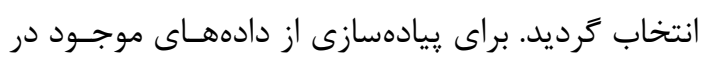

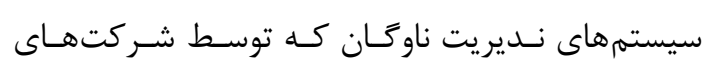

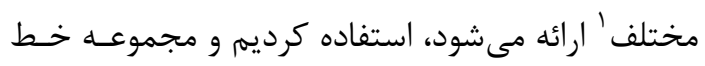

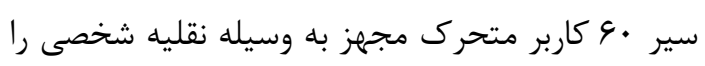

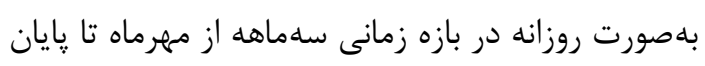

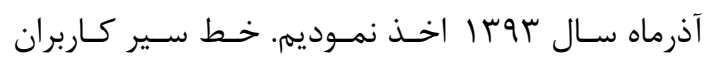

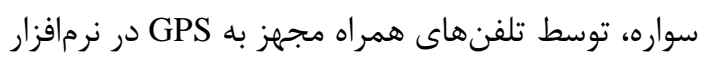
My Tracks

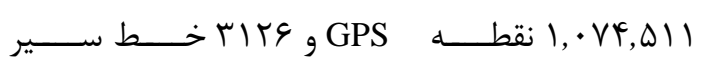

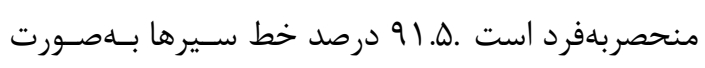

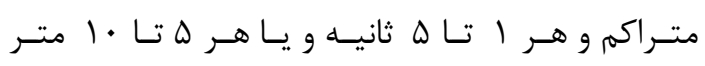

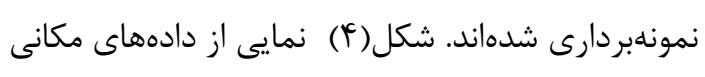

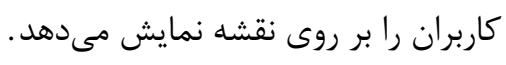

با اصلاح و آمـادهسـازى دادههـا بــر اسـاس مشخصـات

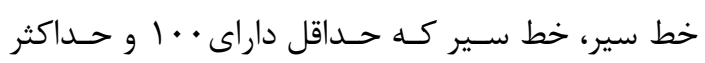

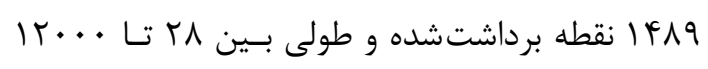

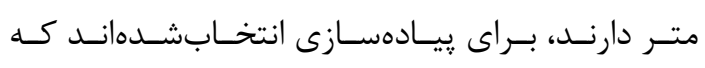
مشخصات آنها در جدول (r) آمده است. F

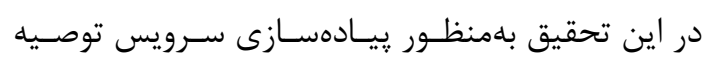

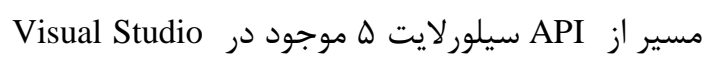

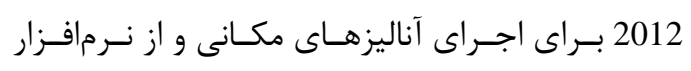
ArcGIS Server 10.2 براى تبادل دادهها و خدمات GIS استفادهشـده اسـت.

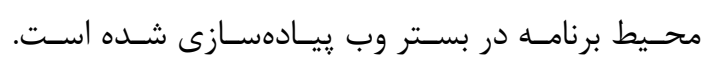

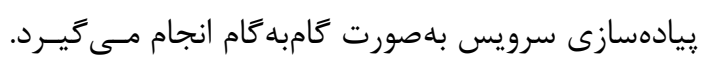

${ }^{1}$ http://www.gpstrack.ir 
كوتــاهتـرين مسـير بــين قطعـهـ خيابـانهـاى محلـى دئى

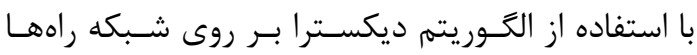

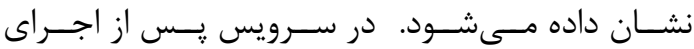

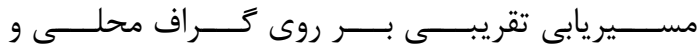

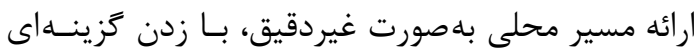

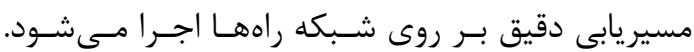

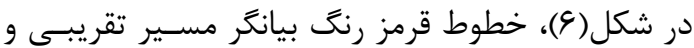

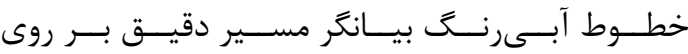
شبكه راهها است.

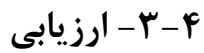

براى ارزيابى عملكرد روش ييشنهادى، نتيجه حاصـل از

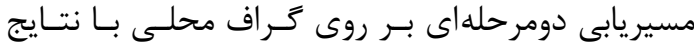
بهدستآمده از روش كوتاهترين مسير مقايسه مىشـود.

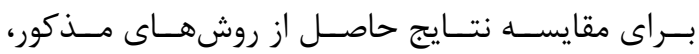

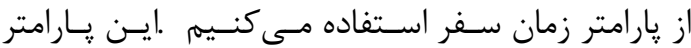

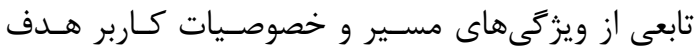
است. براى كسب ويزَّى هاى مسير تمركز مـا در اينجـا

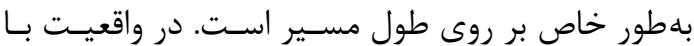

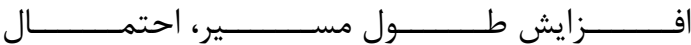

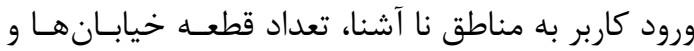

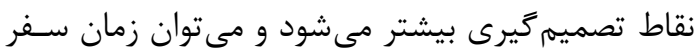

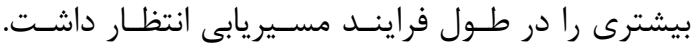

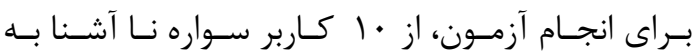

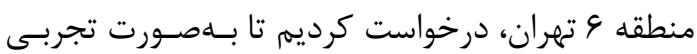

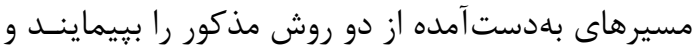

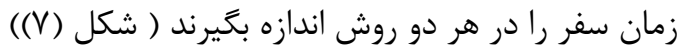

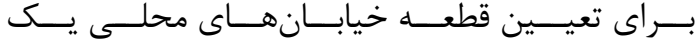

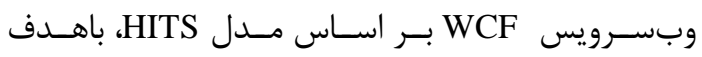
تشخيص ميزان اهميت كاربران و اعتبار قطعه خيابانها

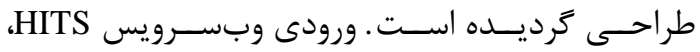

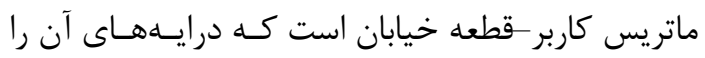
تعداد خط سيرهاى عبورى كاربران از قطعه خيابـانهـا تشكيل مى دهند و خروجى سرويس، يك عدد بين صفر

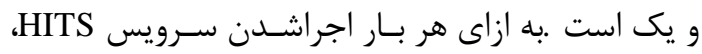

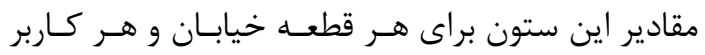

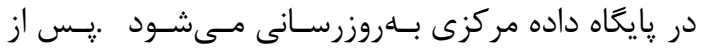
اجراى سرويس HITS، قطعه خيابانهـا و كـاربرانى كـهـ به ترتيب داراى اعتبار و اهميت بيشـتر از هـ • هســتـند، بهعنـوان قطعـه خيابـانهــا و كـاربران محلـى شــناخته

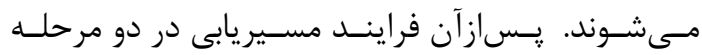

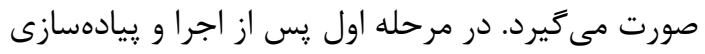
روند مرحلهبهمرحله كراف محلى، مطابق شكل(ه) كراف

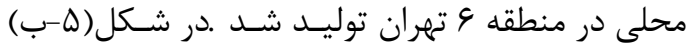

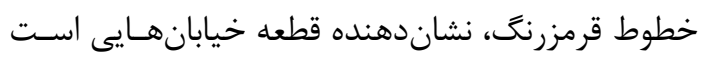

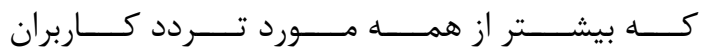

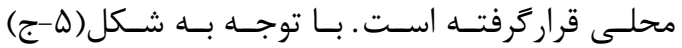
نقاط قرمز رنغ، مراكز اين قطعـه خيابـانهـا بـوده كـهـ

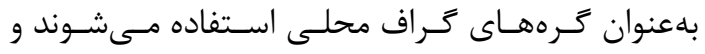
خطوط طوسىرنى نشاندهنده يالهـاى گَراف محلى

هسازآن، كاربر سرويس با تعيين مبدأ و مقصد بـر روى دي

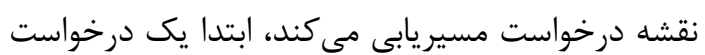
بهطور آنى به سرويس آناليز شبكه بر روى كراف محلـى

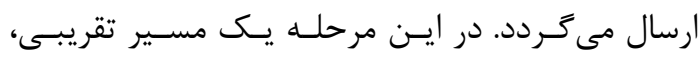



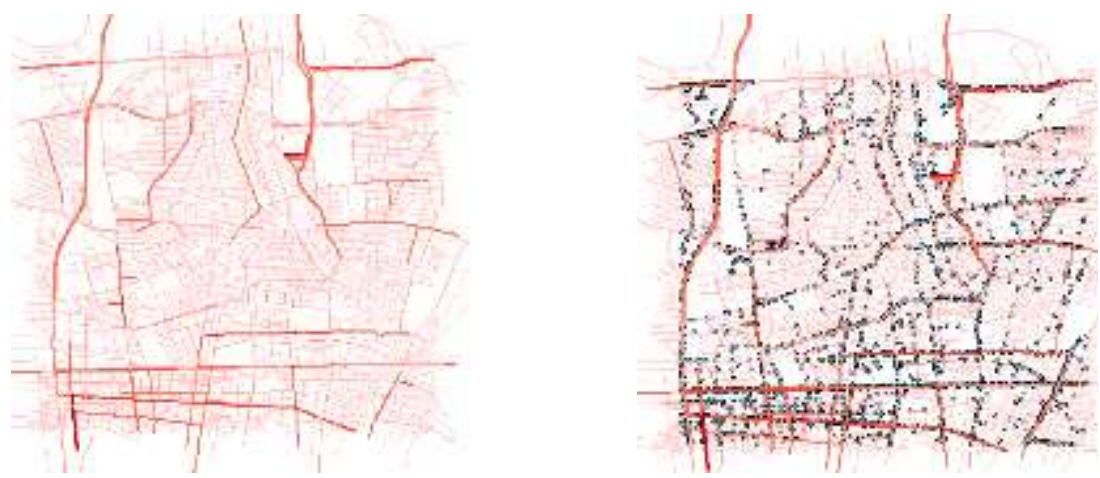

الف) اتصال نقاط GPS بر روى نقشه وزن دهى قطعه خيابانها بر اساس ميزان تردد افراد محلى

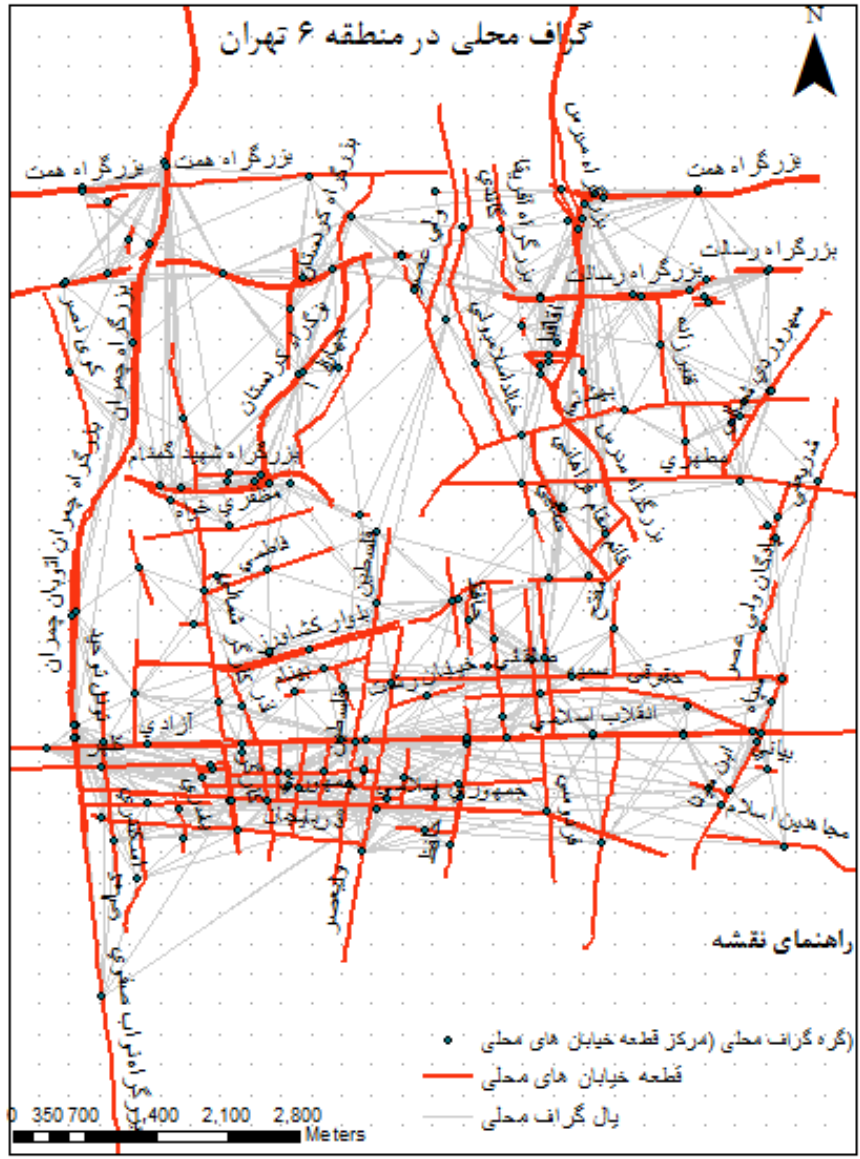

$$
\text { ج) تعيين ترهها و يالهاى تراف محلى }
$$

شكل ه: مراحل ايجاد تراف محلى در منطقه 9 تهران 


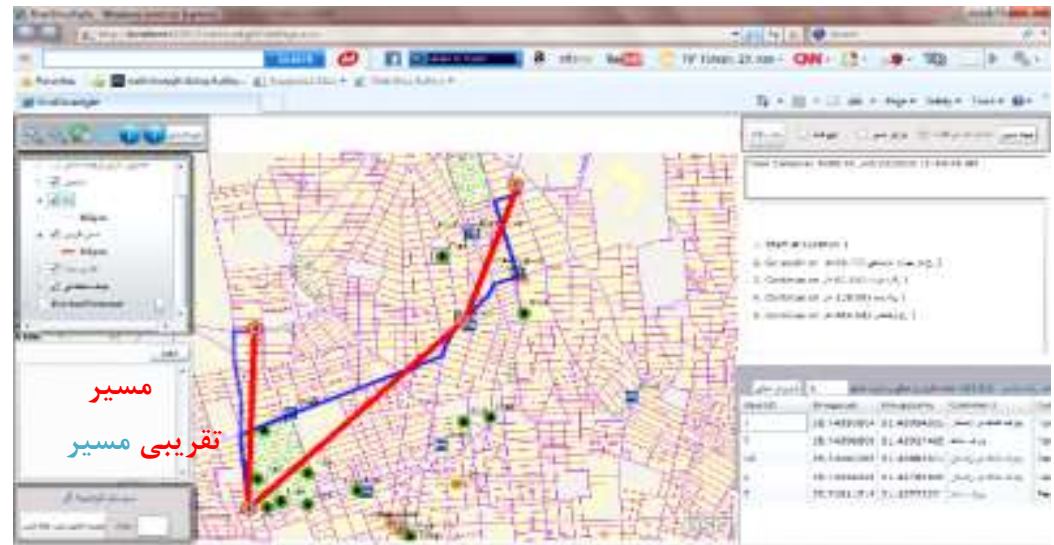

شكل צ: نمايى از مسير يابى دومرحلهاى در سرويس توصيه مسير

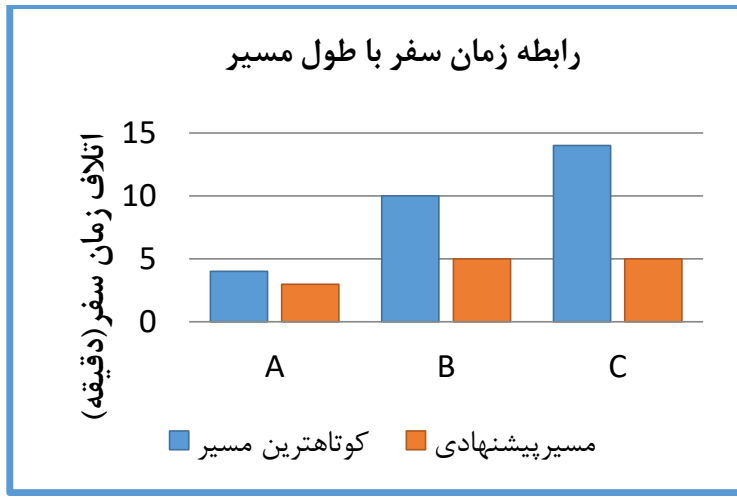

يار ك لاله به

:

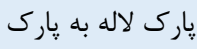

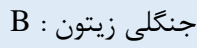
خيابان آيت الله زئه : جله طالقانى به بلوار

آفريقا: C

شكل V: بررسى رابطه زمان سفر با طول مسير براى دو روش مسير يابى

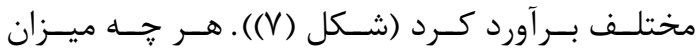
محلى بودن كاربر در يك منطقـه بيشـتر باشــ، ميـزان

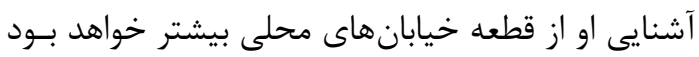

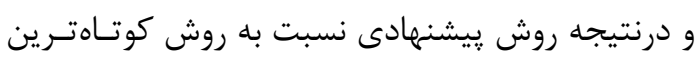

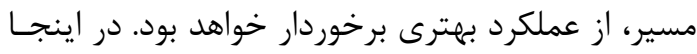

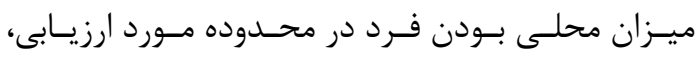

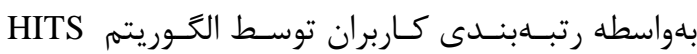

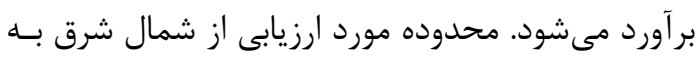

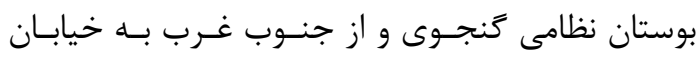

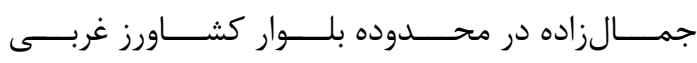
منحصر مى شود و كوتاهترين مسير بـين ايـن دو مكـان

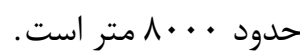

ازآنجايى كه در روش كوتاهترين مسير، وزن دهى قطعـه خيابانها تنها بر اساس طول مسير است، در مقايسه بــا روش ريشنـهادى كه تركيـب طـول مسـير و ترجيحـات كاربران محلى است زمان سفر بيشترى انتظـار مـىرورد.

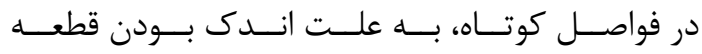

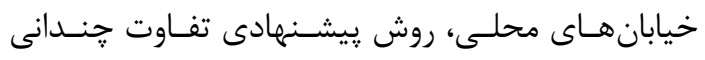

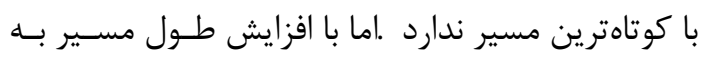

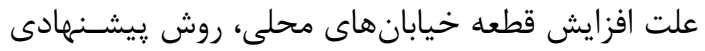
نسبت به روش دايجسترا عملكـرد بهتـرى دارد و زمـان سفر بهطور ميانغين به درصد كاهش مىيابد.

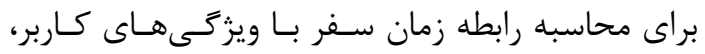
مىتوان به ميزان محلى بودن كاربران در يـك محسـدوده

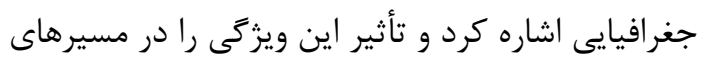




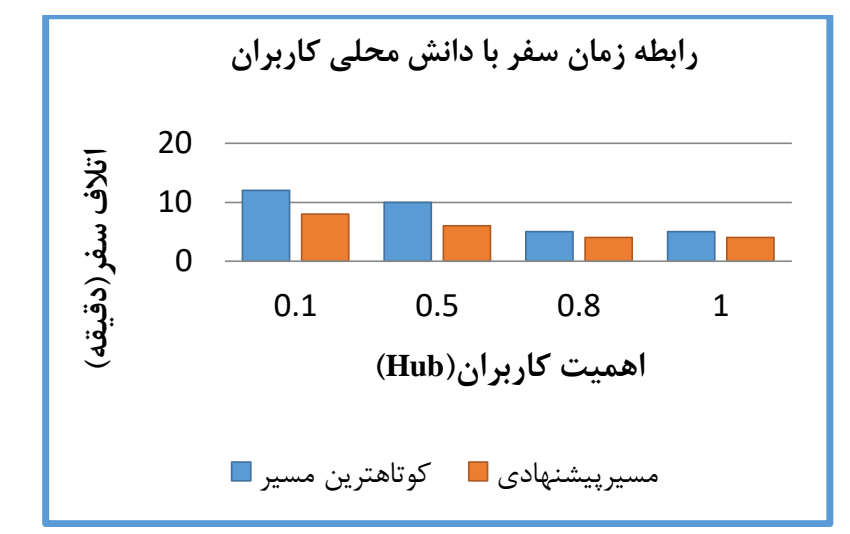

شكل ^: رابطه زمان سفر با دانش منطقهاى كاربران براى دو روش مسيريابى

بتوان با استفاده از مشاركت مردم، حجم كثيرى از ايـن

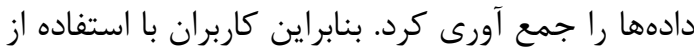

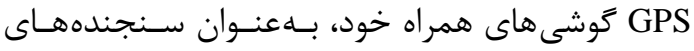
متحركى عمل مى كنند كه ترافيك موجود در خيابانها

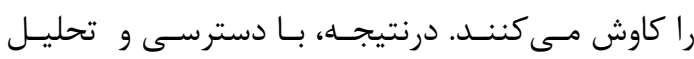

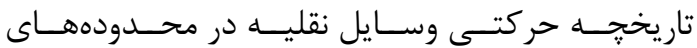

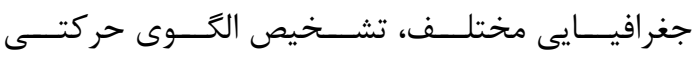

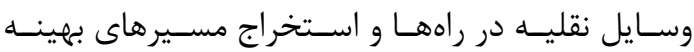

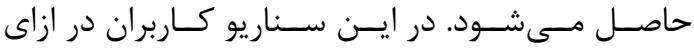

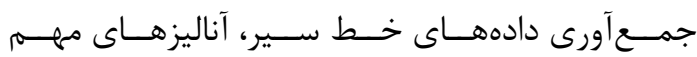

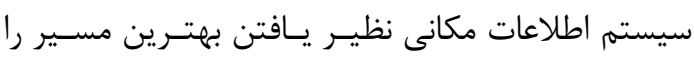

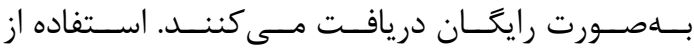
جنين سيستمى مى تواند علاوه بر ترغيب كاربران جهت

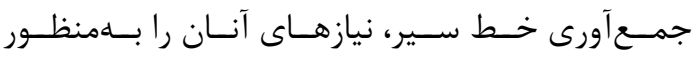
هدايت مناسب در شبكه حمل و نقل برطرف نمايد.

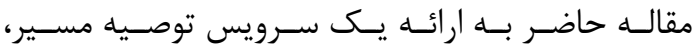

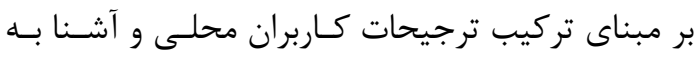

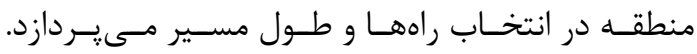

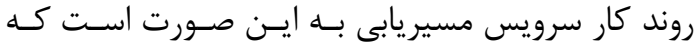

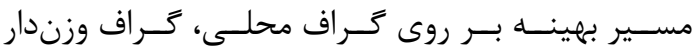

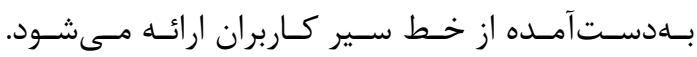

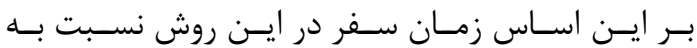
روش كوتاهترين مسير براى طولهاى مختلف و كاربران

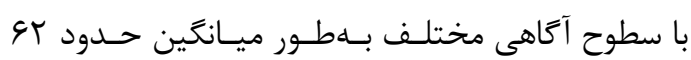

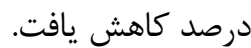

مطابق شكل(^) براى كاربران آشنا به منطقـهـ بـه علـت

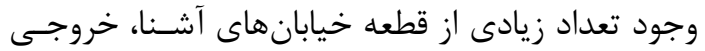
سرويس توصيه مسير به علت عبور از قطعه خيابانهاى

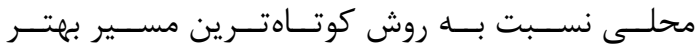

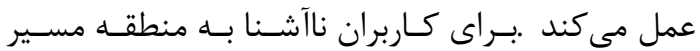
بلهدستآمده از سرويس توصيه مسير نسبت بـهـ مسـير

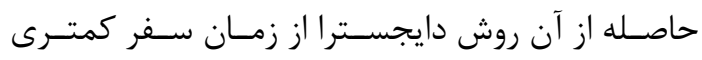

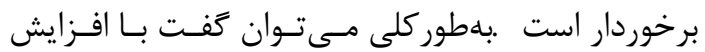
ميزان تسلط كاربران بـهـ منطقـه، زمــان سـفر سـرويس

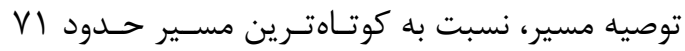

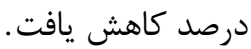

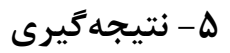

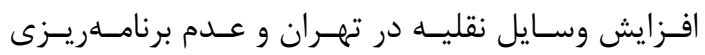
مناسب براى به كنترل درآوردن سفرهاى درونشهري،

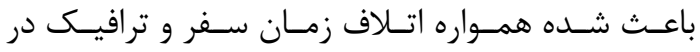

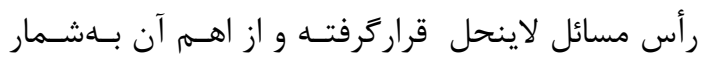
برود. از اين رو ارائه يك سرويس توصيه مسـير مناسـب

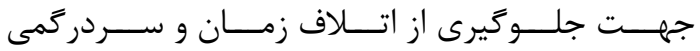

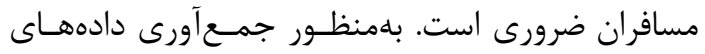

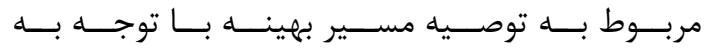

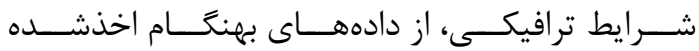

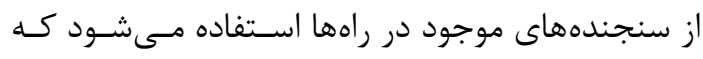

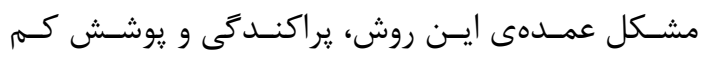
منطقهاى سنجندها است. مجهز شدن تجهيزات همراه به دستكاه كيرنده GPS، نويدبخش شـرايطى اسـت كـهـ 


$$
\text { همكن بـراى ايـن مشـكل اسـتفاده از سـهـ مسـير برتـر }
$$

[1] Bao, Jie, Yu Zheng, David Wilkie, and Mohamed F. Mokbel. "A survey on recommendations in location-based social networks." ACM Transaction on Intelligent Systems and Technology,2013.

[2] Monreale A, Pinelli F, Trasarti R, Giannotti F (2009) WhereNext: a location predictor on trajectory pattern mining. In: Proceedings of KDD 2009, pp. 637-646. doi:10.1145/1557019.1557091.

[3] Giannotti F, Nanni M, Pinelli F, Pedreschi D (2007) Trajectory pattern mining. In: Proceedings of KDD 2007, pp 330-339. doi:10.1145/1281192.1281230.

[4] Krumm J (2010) Where will they turn: predicting turn proportions at intersections. Pers Ubiquit Comput 14:591-599. doi:10.1007/s00779-009-0248-1

[5] Cao L, Krumm J (2009) From GPS traces to a routable road map. In: Proceedings of GIS 2009, pp 3-12. doi:10.1145/1653771. 1653776

[6] Li Q, Zheng Y, Xie X, Chen Y, Liu W, Ma WY (2008) Mining user similarity based on location history. In: Proceedings of GIS 2008,pp1-10. oi:10.1145/1463434.1463477

[7] Ceikute, V., \& Jensen, C. S, "Routing Service Quality--Local Driver Behavior Versus Routing Services", In Mobile Data Management (MDM), 2013 IEEE 14th International Conference on (Vol. 1, pp. 97106), 2013.

[8] Chen, Z., Shen, H. T., \& Zhou, X, "Discovering popular routes from trajectories”, In Data Engineering (ICDE),

$$
\begin{aligned}
& \text { با وجود اينكـهـه روش مـورد اسـتفاده در ايـن مقالـه بـر }
\end{aligned}
$$

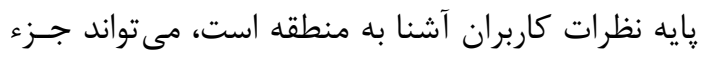

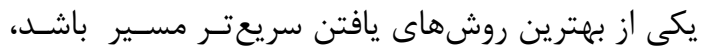

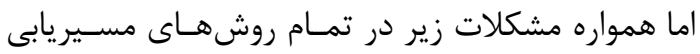

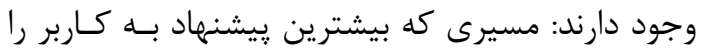

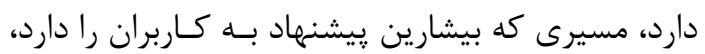

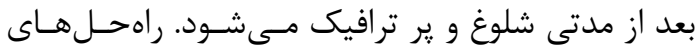

$$
\begin{aligned}
& \text { مراجع }
\end{aligned}
$$

IEEE 27th International Conference on (pp. 900-911), 2011.

[9] Cao L, Krumm J (2009) From GPS traces to a routable road map. In: Proceedings of GIS 2009, pp 3-12. doi:10.1145/1653771. 1653776

[10] Yuan, Jing, et al. "T-drive: enhancing driving directions with taxi drivers' intelligence." Knowledge and Data Engineering, IEEE Transactions on 25.1 (2013): 220-232.

[11] Zheng, Y., Zhang, L., Xie, X.,Ma,W.:Mining interesting locations and travel sequences from gps trajectories. In: WWW, pp. 791-800. ACM (2009).

[12] Yoon, H., Zheng, Y., Xie, X., \& Woo, W. (2012). Social itinerary recommendation from user-generated digital. Pers Ubiquit Comput, 469-484.

[13] Dunstall S, Horn MET, Kilby P, Krishnamoorthy M, Owens B, Sier D, Thiebaux S (2003) An jautomated itinerary planning system for holiday travel. Inf Technol Tour. 6:195-210.

[14] Ardissono L, Goy A, Petrone G, Segnan M (2005). A multi-agent infrastructure for developing personalized web-based systems. ACM Trans Internet Tech 5:47-69. doi:10.1145/1052934.1052936.

[15] Huang Y, Bian L (2009) A Bayesian network and analytic hierarchy process based personalized recommendations for tourist attractions over the Internet. Expert Syst Appl 36:933-943. doi: 
10.1016/j.eswa.2007.10.019

[16] Chodhury MD, Feldman M, Amer-Yahia S, Golbandi N, Lempel R, Yu C (2010) Automatic construction of travel itineraries using social breadcrumbs. In: Proceedings of HT 2010, pp 35-44. doi: $10.1145 / 1810617.1810626$

[17] Gonzalez, H., Han, J., Li, X., Myslinska, M., \& Sondag, J. P. (2007, September). Adaptive fastest path computation on a road network: a traffic mining approach. In Proceedings of the 33rd international conference on Very large data bases (pp. 794-805). VLDB Endowment.

[18] Yuan, J., Zheng, Y., Zhang, C., Xie, X., \& Sun, G. Z, "An interactive-voting based map matching algorithm", In Proceedings of the 2010 Eleventh International Conference on Mobile Data Management (pp. 43-52). IEEE Computer Society, 2010.

[19] Kleinberg, J. M,"Authoritative sources in a hyperlinked environment", Journal of the ACM (JACM), 46(5), 604-632, 1999.

[20]Zheng, Y., \& Zhou, X, Computing with spatial trajectories. Springer Science \& Business Media, 2011.

[21] Liben-Nowell, D., Novak, J., Kumar, R., Raghavan, P., and Tomkins, A. (2005) Geographic routing in social networks,Proceedings of the National Academy of Sciences of the United States of America 102, 11623.

[22]Chang, K. P., Wei, L. Y., Yeh, M. Y., \& Peng, W. C. (2011, November). Discovering personalized routes from trajectories. In Proceedings of the 3rd ACM SIGSPATIAL International Workshop on Location-Based Social Networks (pp. 3340). ACM. 


\title{
Route recommendation based on local users' trajectories
}

\author{
Roya Shurouni $^{1 *}$, Mohammadreza Malek ${ }^{2}$
}

1- M.Sc. student of geographic information system in Department of Geomatics, College of Engineering, Khaje Nasir Toosi University. 2-Associate professor in Department of Geomatics, College of Engineering, Khaje Nasir Toosi University.

\begin{abstract}
Large amount of users' trajectories, is an emerging source of inexpensive data that can be used to provide an opportunity to present route recommendation service to the unfamiliar users within the area. In this study, with the aim of finding the optimal route, we first extract both local users and local road segments data sets by ranking them via HITS algorithm. In this model, a hub is a user who many time has crossed many road segments of a region, and an authority is a road segment that has been crossed by many users. Therefore, users' travel experiences (hub scores) and the interests of road segments (authority scores) have a mutual reinforcement relation. We also propose a novel approach in which the basic unit of routing is separate road segment instead of GPS trajectory segment. Moreover, to provide the approximate routing, we create a local graph. The center of the local road segments are considered as nodes and are based on local streets sequence arrange the pieces obtained from the trajectory of the user as edges of local graph. According to this graph, two steps of routing are used to obtain the optimal path. Then using Dijkstra's algorithm on the main road network and obtained an approximate route, shortest route between two local road segments based on this graph is used to obtain the optimal route. To implement and test, used data, from the trajectories of moving users in Tehran, has been gathered for 3 months on daily basis. To evaluate performance of the two-step routing, we experimentally compared the travel time in proposed route to Dijkstra's shortest path for different lengths and users with different levels of regional knowledge. The travel time in the proposed method was decreased 60 percent compare to shortest route.
\end{abstract}

Key words: Recommendation system, Route planning, Trajectory collection, Ranking.

Correspondence Address : GIS Group, Department of Geomatics, College of Engineering, University of Tehran, Tehran, Iran Tel : +98912 5646641

Email : Shourouni@mail.kntu.ac.ir 